\title{
Article \\ Experimental Analysis of a Fish Guidance System for a River Water Intake
}

\author{
Gabriela Cîrciumaru ${ }^{1, *(\mathbb{D})}$, Rareș-Andrei Chihaia ${ }^{1}$ D , Andreea Voina ${ }^{1}$, Daniela-Elena Gogoașe Nistoran ${ }^{2}$, \\ Ștefan-Mugur Simionescu ${ }^{2} \mathbb{D}$, Lucia-Andreea El-Leathey ${ }^{1}$ and Lucian Mândrea ${ }^{2}$
}

Citation: Cîrciumaru, G.; Chihaia, R.-A.; Voina, A.; Gogoașe Nistoran, D.-E.; Simionescu, S.-M.; El-Leathey, L.-A.; Mândrea, L. Experimental Analysis of a Fish Guidance System for a River Water Intake. Water 2022, 14, 370. https://doi.org/10.3390/ w14030370

Academic Editors: Dibyendu Sarkar, Rupali Datta, Prafulla Kumar Sahoo and Mohammad Mahmudur Rahman

Received: 9 December 2021 Accepted: 23 January 2022 Published: 26 January 2022

Publisher's Note: MDPI stays neutral with regard to jurisdictional claims in published maps and institutional affiliations.

Copyright: (c) 2022 by the authors. Licensee MDPI, Basel, Switzerland. This article is an open access article distributed under the terms and conditions of the Creative Commons Attribution (CC BY) license (https:// creativecommons.org/licenses/by/ $4.0 /)$.
1 National Institute for R\&D in Electrical Engineering ICPE-CA, 030138 Bucharest, Romania; rares.chihaia@icpe-ca.ro (R.-A.C.); andreea.voina@icpe-ca.ro (A.V.); andreea.elleathey@icpe-ca.ro (L.-A.E.-L.)

2 Faculty of Energy Engineering, University Politehnica of Bucharest, 060042 Bucharest, Romania; daniela.nistoran@upb.ro (D.-E.G.N.); s.simionescu@upb.ro (Ș.-M.S.); lucian.mandrea@upb.ro (L.M.)

* Correspondence: gabriela.circiumaru@icpe-ca.ro; Tel.: +40-721-409-547

\begin{abstract}
This paper describes the experimental study of a behavioural barrier consisting of a bubble curtain placed near an ecological river water intake, aiming to assess the bubble curtain's influence on the velocity field of water flowing in the water intake proximity. The scientific novelty is given by the water intake solution operating in tandem with the dedicated bubble curtain generator used for avoiding fish entrapment. The water intake solution used in the present research is based on a run-of-river intake without a dam in the riverbed, maintaining the mountain rivers longitudinal connectivity. An experimental setup was designed and built to study the behavioural barrier for ecological water intakes in different operating conditions. Thus, tests were performed for two water velocities $(0.33 \mathrm{~m} / \mathrm{s}$ and $0.535 \mathrm{~m} / \mathrm{s})$ in the experimental setup, two water depths (92 $\mathrm{mm}$ and $119 \mathrm{~mm})$ and two air flow rates (10.5 LPM and 15 LPM). The results were compared with the case when no air is injected through the bubble curtain generator. The assessment of the bubble curtain influence on the water flow inside the channel was made by measuring and analysing the velocity variation in vertical and horizontal direction. The results showed a significant velocity gradient in the bubble curtain proximity, which can contribute to influencing the behaviour of the fish by deterring them from the water intake area.
\end{abstract}

Keywords: bubble curtain; fish guidance system; water intake; fish protection

\section{Introduction}

There are many issues that put the development of society in conflict with the sustainability and conservation of the environment, and one of them is given by the need to use water sources. The two aspects-the use of water resources and the conservation of the environment-must be approached simultaneously by solutions that meet specific situational needs. In recent years, the scientific community has begun to study the behavioural characteristics of native fish species in mountain rivers. Lately, rivers have undergone profound transformations in order to be used for economic and social activities. The general decline of fish populations and aquatic fauna specific to watercourses, or even the extinction of some species, are indicators of environmental degradation. This decline is due to both climate change (especially through changes in the hydrological and thermal regime of the watercourses [1]) and anthropogenic factors; it must be limited by all possible and responsible means. Freshwater species registered a significant decline in the last 50 years. The Living Planet Index, which measures trends in thousands of populations of mammals, birds, reptiles, amphibians and fish across the globe, proposed by the World Wide Fund for Nature [2], shows a decrease of $81 \%$ between 1970 and 2012. Among the anthropogenic factors that negatively influence the fishing population of watercourses, the following are worth mentioning: excessive water exploitation, artificialisation of rivers through nonintegrated arrangements in the environment, industrialisation, intensive fishing, etc. [3]. 
These actions significantly impact fish population, the main threats being represented by habitat loss and degradation [2]. Aquatic biodiversity loss is mainly caused by the interruption of longitudinal connectivity due to the presence of hydropower facilities, which block the stream, and to the lack of passageways for migratory species. There are enough known cases where morphological changes of rivers used for economic reasons affected their ecological functions [4]. In the second half of the twentieth century, the hydrotechnical constructions across watercourses have significantly interrupted the longitudinal continuity of many rivers, causing a change in the natural hydrological regime and preventing the migration of fish to areas suitable for wintering, breeding, rearing or feeding. This effect on ecosystems must be taken into consideration, bearing in mind that, according to Grill et al. [5], 48\% from the total river volume is subject to flow regulation and/or fragmentation. The longitudinal hydrotechnical constructions (piers) prevented the lateral continuity of the river, as the flooding of the meadows could not take place and the ecological exchange of fertile material and aquatic flora/fauna between the rivers and wetlands in the major riverbeds could not be performed; this changed the hydrological regime [1], the morphology of the riverbed [6-8] and the structure of its bed substrate [8-10].

Another negative impact on fish is created by the operation of water intakes located on rivers. Water intakes contain diversion or bypass installations/constructions for directing and catching river water. The choice of arrangements to ensure the exclusion of fish and their efficiency depends largely on the characteristics of the fish species in the targeted river sections and are related to size, stages of life and reproduction, behaviour and preferred routes. If it is desired to exclude small fish, the slots of the grills must be narrowed and the access speeds reduced to prevent their suction. The screen is the main element of the water intake; it provides protection against the access of solid materials, fish, other impurities and floating debris. From a constructive point of view, the screen consists of metal bars, vertical or inclined at a certain angle, with a rectangular cross section, connected in panels. For metal or reinforced concrete strength beams, a hydrodynamic shape is generally preferred. To avoid fish entrapment, the screen openings must be reduced as much as possible. Often, this is not possible due to the local head losses increase which is proportional to the water velocities; in addition, the risk of clogging also increases. Furthermore, if the screen is not properly designed, the fish can enter through the screen openings into pipelines/channels /penstocks. Thus, for fish protection, other means of deviation should be applied.

The most important provisions on environmental law were imposed by the Water Framework Directive. Under these provisions, rivers must be protected, enhanced and rebuilt in order to achieve both good status of surface water and also a good ecological potential. Barring work of watercourses must be provided with facilities to ensure the required flow downstream, and, where appropriate, special facility for fish migration [11].

Since the 1980s, different solutions for fish screening on water intakes have been adopted. Studies have led to the elaboration of a best practice guide in the UK, in 2005, [12], regarding the use of fish guidance systems. In order to protect fish populations, both from accidentally entrapment in water intakes/diversions and from invasive species, several solutions have been proposed and used. These solutions fall into two broad categories [13]: direct means of excluding fish-physical barriers or positive barriers screens (specially designed screens or sieves, fixed or rotating) — and indirect solutions which influence the behaviour of aquatic population-non-physical barriers or behavioural barriers (designed to keep fish away from the intake area and based on bubble curtains, strobe light, sound, electricity, magnetic fields or by changing direction and velocity of the water flow). The nonphysical guidance systems (behavioural barriers) are based on the natural behaviours of fish-of attraction in the fish ladders case or repelling in the water intakes/catchments case.

The water intake solution used in the present research is based on a run-of-river intake without a dam in the riverbed, maintaining longitudinal connectivity of the mountain rivers. In addition, compared to traditional physical systems for fish guidance, the proposed behavioural barrier has the advantage to easily adapt to the flowing conditions of the river. Taking into consideration that each fish species has specific characteristics/features 
(different size, shape and swimming capabilities, different development stages, habits and life cycle, different features-hearing specialists or generalists respond to certain stimuli, etc.), studies have been undertaken to determine the effectiveness of several types of barriers/configurations in guiding or deterring fish in various operation conditions. This paper approaches the experimental study of a behavioural barrier consisting of a bubble curtain placed near an ecological water intake (perforated plate screen) to evaluate the results obtained and make recommendations for large-scale use. The scientific novelty is given by the water intake solution operating in tandem with a dedicated bubble curtain generator which helps to avoid accidental entrapment of fish fauna.

\section{Fish Guidance Systems Based on the Use of Non-Physical Barriers}

Fish guidance systems have been used over the years to discourage migration and to direct species of interest away from anthropogenic hazards. For example, non-physical guidance/deterrence systems have been used to target commercial or recreational fish around facilities such as hydropower dams, which may threaten their survival, as shown by Taft [14]. There is a critical need for methods and technologies to stop the spread of exotic organisms through natural and human-mediated means, especially in Canada and in the US Great Lakes region (and not limited to these areas), as the area has been invaded by more than 180 invasive species in the last 200 years, according to the US National Oceanic and Atmospheric Administration [15] and to Mills et al. [16]. One method consists in the placement of barriers to intervene in the movement of species. Unlike most terrestrial fauna, fish movement can be discouraged both by physical obstacles placed on waterways and by non-physical methods that change their behaviour. According to Noatch and Suski [17], non-physical deterrence can be defined as "any stimulus or non-solid obstruction that discourages or prevents a selected species from passing through a target region".

Thus, the behavioural barriers represent alternative solutions to the classical barriers to guide fish. Current technologies are not suitable for locations with shallow water depths and rapid change level. As reported by Zielinski 2011 [18], for such locations, bubble curtains may be the right solution. The bubbles generate distinct acoustic and hydrodynamic fields, and by proper handling, could be used to guide juvenile fish.

According to the U.S. Department of Interior [13], the main advantages of behavioural systems are the following: they are easy, safe and cheap to maintain, can also be applied in locations where it would be difficult to install screens; in addition, they are environmentally friendly and do not hurt or kill fish. The disadvantages of behavioural systems include that they do not create an absolute barrier to exclusion and their efficiency varies with the species, fish development stage, environmental conditions (flow and variability), water quality and lighting.

In order to reduce the operating costs, any barrier installed on a watercourse has to not retain the floating debris (to avoid clogging) or to require frequent maintenance. In addition, the remote locations where they are placed restrict the access to the available power supply infrastructure. In addition, the barrier must be flexible to the changes in the water level and flow in order to cope with seasonal floods. There are several guidance systems for fish which are based on stimuli that most fish are able to detect: sound waves, light, chemical stimuli, pressure waves and electricity. As reported by Taylor et al. [19], there are also devices that combine several types of stimuli. Combined barrier systems require more space to place all the equipment and can be difficult to install on shallow watercourses.

Given that behavioural barriers are based on the use of different types of stimuli, this paragraph provides a brief description of the main types of barriers. Electric barriers consist of a series of metal anodes and cathodes placed in water. Electric current passes through the water from an anode to a cathode creating an electric field near the barrier, and their efficiency in guiding fish is due to the behavioural avoidance of electric fields. Electric barriers have two major limitations: they can be disabled by power failure, maintenance (or lack thereof) and human error, and they are not effective for small fish, which are not affected by electric fields. Thus, additional guidance systems are recommended. In 
the case of visual barriers (strobe lights), ambient light levels influence fish behaviour, including orientation, food location, communication between species, circadian movements and predator avoidance. Strobe lights introduce unnatural light levels relative to the environment, with the ability to induce an avoidance response in fish. For increased efficiency, they should be used as part of an integrated deterrent system (e.g., bubble curtains). Acoustic fish guidance systems are applied when in situ conditions exclude the use of visual stimuli to induce fish avoidance behaviours; thus, sound and pressure waves may be a viable alternative. Sound generated in the water consists of pressure waves that can be detected by fish. The effectiveness of acoustic systems in fish guiding can be influenced by bottom morphology, hydrology and sound waves angle. Low-frequency sound waves do not propagate well in shallow water and on hard substrates. Velocity barriers consist of changing flow regimes within a watercourse or channel so that the water velocity exceeds the swimming capacity of the target species and can only be implemented on a small scale. When dealing with running water, all fish have inherent physiological limitations; thus, high water velocity acts as a barrier to fish movement. For hypoxia and hypercapnia, the method consists of using toxic chemicals to exclude aquatic organisms from specific locations by creating hypoxic/hypercapnic barriers. To ensure efficiency, tolerance thresholds for target and non-target fish must be first quantified. Dissolved gas barriers have the potential to be effective in all sizes of fish once a certain threshold is reached (e.g., DO level of approximately $1.5 \mathrm{mg} / \mathrm{L}$ [20]). Pheromones are generally defined as secreted chemical odours that elicit a specific behavioural response in living things of the same species. As a potential chemical barrier for fish, pheromones could be collected or synthesised and released into the water column to drive fish away from a particular location, or to gather fish away from a danger source or an enclosed passageway. The effectiveness of the utilisation of electromagnetic fields barriers is based on the fact that many aquatic organisms, including cartilaginous fish and neopterygian bone fish, have electroreceptive organs capable to detect the electric fields in water. Thus, strong magnetic fields can overstimulate these receptors, causing a deterrent or repellent effect, which can be useful in directing organisms away from their target locations. Behavioural barriers based on the use of bubble curtains are a relatively low cost and maintenance option that do not interfere with the watercourse morphology. They combine two stimuli-velocity and sound-and could be exploited to discourage the migration of fish or their entrapment in river water intakes. The bubble curtain is emitted by air diffusers, perforated pipes, or porous hoses placed along the bottom of the watercourse, perpendicular to the channel or river, respectively. It acts like a continuous screen in the water body and makes an unusual visual effect that fish generally avoid. As bubble curtains do not emit their own light, they should operate in water with low turbidity; in addition, in order to increase their efficiency and to be easily seen from distance, they should operate along with a light source.

First study on non-migratory freshwater fish entrapment was performed by Hadderingh in 1982 [21], reporting intake rates of up to 25 million juveniles per day at a Dutch power plant (Bergum) in Friesland. The fish were entering through the screens of the cooling water inlets especially in no-light conditions. Thus, in order to help fish to orientate and to diminish their entrapment in the intake area, it was artificially illuminated. This led to a significant decrease in the intake rate, especially for ruffe (Gymnocephalus cernua) and perch (Perca fluviatilis). The interest in using artificial illumination or other means for diminishing the fish entrapment rates has grown steadily worldwide, leading the experts to publish a series of papers or research reports [12,13,21-37] which deal with the effectiveness of different fish guidance systems, either by performing laboratory studies or by evaluation in situ. Besides the intensive fishing, the implementation of water diversions led to the emergence of numerous endangered fish species. The increased intensity of the modern mobility of freight and people, that through the ballast water carried by vessels constantly introduced and spread invasive fish species in different environments, also contributed to this situation. In these conditions, the importance of fish protection at water intakes, small dams, and water diversion structures became significant. This led to the 
elaboration of guides for fish exclusion facilities. For example, the U.S. Department of the Interior [13] approached a series of fish protection-related subjects such as legislation, designing/choosing fish exclusion facilities depending on the target fish characteristics (species, size, life stage, behaviour, swimming ability), analysis of barriers type (classification, constructive characteristics, velocity/flow-related characteristics, maintenance, advantages and disadvantages, etc.).

Blake et al. [22] performed research concerning the use of a sound-bubble-strobe light (SBSL) barrier to limit the invasion of Asian carp (bighead carp, Hypophthalmichthys nobilis, and silver carp, Hypophthalmichthys molitrix) in the Mississippi River Basin. These carps influenced the native fishes, especially in Illinois River. A $16 \mathrm{~m}$ wide SBSL has been deployed perpendicular to the flow of Quiver Creek. The water flow velocities ranged from $0.4 \mathrm{~m} / \mathrm{s}$ to $0.8 \mathrm{~m} / \mathrm{s}$, while the maximum water depth was $1 \mathrm{~m}$. A hose was used to generate air bubbles, and underwater speakers were used to emit sound frequencies between 500 and $2000 \mathrm{~Hz}$ and L.E.D. lights to flash intermittently or permanently. The tests were performed in different conditions/configurations of the barrier, namely, using sound, bubbles, and strobe lights or only sound and bubbles. The effectiveness of the barrier ranged from $94.1 \%$ to almost $100 \%$, depending on the fish species (e.g., Cyprinidae $96.9 \%$, Percidae $96 \%$, Centrarchidae-Sunfish 97.5\%, Ictaluridae 98.9\%, Moronidae 100\%), suggesting that the SBSL barriers could be used as a deterrent system to repel Asian carp, to prevent its expansion in Mississippi River Basin. Zielinski and Sorensen [24] explored the theory and application of a bubble curtain deflection screen using a split-passage experimental channel equipped with angled bubble curtains to test two Asian carp species (bighead and silver carp) and the Common carp (Cyprinus carpio) to see if they avoid bubble curtains. The bubble curtain was created using a $\mathrm{S} 41$ regenerative air blower at $5 \mathrm{kPa}$ to supply $12 \mathrm{~L} / \mathrm{s}$ of air thorough $1 \mathrm{~m}$ of water. It was found that the bubble curtains reduced in $73-80 \%$ the passage of all three species through the experimental channel while producing sound between 100 and $1000 \mathrm{~Hz}$ at $145 \mathrm{~dB}$. As the bubble curtain deterrence system produced the same effects on the three tested Asian carp species, Zielinski and Sorensen [24] concluded that the Common carp could be used instead of Asian carp when performing field experiments in areas where this invasive species is not yet very numerous, like the case of upper Mississippi River. By following this approach, insight on the efficiency of the bubble curtains in inhibiting the movement of Asian carp was obtained, with minimal impact on other fish living in the studied area. Jesus et al. [26] tested the use of acoustic barriers as an acoustic deterrent for native potamodromous migratory fish species (Salmo trutta, Pseudochondrostoma duriense, and Luciobarbus bocagei) from Iberia. The tests showed that the endemic cyprinids showed a strong repulse reaction to the frequency sweep-up sound. The $140 \mathrm{~Hz}$ stimulus did not significantly alter the behaviour of any of the studied species. These results highlight the potential of acoustic stimuli as fish behavioural barriers and can be used selectively on target species. Leander et al. [27] investigated experimentally in laboratory and in situ the efficiency of bubble barriers in diverting migrating Atlantic salmon (Salmo salar). Acoustic telemetry was used to measure the interaction of salmon with the bubble barrier. An efficiency between $90 \%$ and $95 \%$ in diverting the migrating salmon was found. In the literature, studies and reviews also reported on the use of different behavioural barriers [28,38-40]. Zielinski et al. (2019) [28] presented the effectiveness of current and alternative barrier technologies in invasive sea lamprey (Petromyzon marinus) control in the Laurentian Great Lake. The invasion started in the early 1900s and negatively affected the fisheries and local economies. Therefore, since the 1950s an integrated pest management program was initiated that led to a reduction in sea lamprey numbers by $90 \%$. The barriers are critical in the effectiveness of this control program, which is one of the most successful programs. The invasion is controlled by using both lampricide to kill the larvae and physical barriers to block the access of adult sea lamprey to spawning areas. There are almost 100,000 barriers that stops/dimmish the movement of fish between lake and tributary on Great Lakes tributaries. Most of these potential barriers to fish movement have been built for other purposes, while approximately 8000 were built or 
modified to control the sea lamprey. Jones et al. [39] and Jesus et al. [40] conducted a literature search in different databases to identify the reported research concerning the use of barriers in limiting the invasive species and/or in guiding the freshwater fish. The importance and relevance of this issue is reflected by the significant number of articles identified -87 titles in Jones et al. [39] and 123 in Jesus et al. [40]. The performed research concerns the use, characteristics, efficiency, etc. of different type of barriers operating alone or in different combinations.

The studies reported in literature on the use of bubble curtains to guide fish focus on a wide range of species: Asian carp (Hypophthalmichthys nobilis, Mylopharyngodon piceus, Ctenopharyngodon Idella, Hypophthalmichthys molitrix) [19], Atlantic salmon, Eurasian ruffe (Gymnocephalus cernua), herring (Alosa pseudoharengus, Dorosoma cepedianum, Brevoortia tyrannus) [29]. The use of a bubble curtain in combination with a sound source has been studied by Taylor et al. [19] and by Welton et al. [41]. The bubble curtain was generated by injecting air flow rates of $0.1-1 \mathrm{~L} / \mathrm{s} \cdot \mathrm{m}$ through a PVC pipe with holes drilled in it. Experimental results showed a 95\% decrease in Asian carp migration [19], respectively, a $20-40 \%$ efficiency in guiding smolt (young Salmo salar) during the day and more than $70 \%$ at night [40]. These studies did not consider the bubble curtain as the primary guidance solution, nor did they analyse in detail the physical fields generated by it. Studies conducted at the site of a hydroelectric plant in Michigan, USA [13], have shown that choosing a mixed method by coupling bubble curtains with strobe lights can increase the efficiency (fish exclusion rate) of the bubble barrier. For example, in the Richard B. Russell project in the United States [13], the use of high-frequency sounds combined with light systems proved to be very effective in deterring herring from the water intakes pumps in safety areas with lower velocities. Several studies indicate higher rates of deterrence when bubble barriers are associated with an additional light source, such as strobe lights [31] or sound [39]. Welton et al. [39] reported that an experimental barrier consisted of a bubble curtain coupled with deterrent acoustic elements has an efficiency of $95 \%$ in limiting the movements of the Asian carp. Therefore, other combinations of guidance systems based on the fish behaviour could also be expected to improve their barrier efficiency.

The data in Table 1 have resulted from analysing different options for non-physical deterrence of fish movements [17,18,29,42-46]. It summarises the different non-physical barriers that could be implemented to deter/guide fish movements, the advantages and disadvantages of different types of barriers, as well as the conditions that lead to their successful implementation.

Table 1. Types of behavioural barriers (adapted from the works in $[17,18,29,42-46]$ ).

\begin{tabular}{|c|c|c|c|c|}
\hline Barrier Type & $\begin{array}{l}\text { Implementation } \\
\text { Conditions }\end{array}$ & Description & Advantages & Disadvantages \\
\hline Electric & $\begin{array}{c}\text { Site with suitable } \\
\text { power supply; Suitable } \\
\text { water conductivity }\end{array}$ & $\begin{array}{c}\text { Electric current } \\
\text { produced by electrodes } \\
\text { located on the channel } \\
\text { perimeter }\end{array}$ & $\begin{array}{l}\text { It has proven highly } \\
\text { effective against } \\
\text { upstream migrating fish }\end{array}$ & $\begin{array}{l}\text { Expensive equipment and } \\
\text { maintenance; risk to } \\
\text { human and animal health; } \\
\text { it is not specific to a species }\end{array}$ \\
\hline $\begin{array}{l}\text { Visual- } \\
\text { strobelights }\end{array}$ & Low water turbidity & $\begin{array}{l}\text { Strobe light with set } \\
\text { water flashing } \\
\text { frequency }\end{array}$ & $\begin{array}{l}\text { Relatively small } \\
\text { influence on water flow; } \\
\text { adaptable to flow; in } \\
\text { some species, very } \\
\text { effective in combination } \\
\text { with bubble curtains }\end{array}$ & $\begin{array}{l}\text { It depends very much on } \\
\text { the natural light level; } \\
\text { cloudy water reduces its } \\
\text { efficiency, and this is not } \\
\text { proven in all species }\end{array}$ \\
\hline
\end{tabular}


Table 1. Cont.

\begin{tabular}{|c|c|c|c|c|}
\hline Barrier Type & $\begin{array}{l}\text { Implementation } \\
\text { Conditions }\end{array}$ & Description & Advantages & Disadvantages \\
\hline Acoustics & $\begin{array}{l}\text { Site with suitable } \\
\text { acoustic characteristics }\end{array}$ & $\begin{array}{l}\text { Underwater speaker } \\
\text { with specified signal }\end{array}$ & $\begin{array}{l}\text { Flexible to different flow } \\
\text { conditions; species } \\
\text { specific potential; wide } \\
\text { range of sounds }\end{array}$ & $\begin{array}{l}\text { Variable efficiency; the } \\
\text { frequencies } \\
\text { must be selected according } \\
\text { to species; expensive } \\
\text { equipment that can clog }\end{array}$ \\
\hline Bubble curtains & $\begin{array}{l}\text { Low water turbidity, } \\
\text { relatively shallow } \\
\text { water }\end{array}$ & $\begin{array}{l}\text { Compressed air } \\
\text { emitted as bubbles } \\
\text { through diffusers }\end{array}$ & $\begin{array}{l}\text { Flexible in different flow } \\
\text { conditions; multiple } \\
\text { physical stimuli; } \\
\text { relatively simple } \\
\text { construction; reduced } \\
\text { cost. The efficiency } \\
\text { increases in combination } \\
\text { with other types } \\
\text { of barriers }\end{array}$ & $\begin{array}{l}\text { The bubbles can be } \\
\text { "washed" at high flow } \\
\text { rates; it cannot work in } \\
\text { all conditions }\end{array}$ \\
\hline Water velocity & $\begin{array}{c}\text { Target species (a weak } \\
\text { swimmer); narrow } \\
\text { channel, } \\
\text { adequate water flow }\end{array}$ & $\begin{array}{l}\text { Based on local change } \\
\text { in water flow velocity }\end{array}$ & $\begin{array}{l}\text { Selectively excludes } \\
\text { disturbing species }\end{array}$ & $\begin{array}{l}\text { Major channel change; } \\
\text { few sites meet the criteria }\end{array}$ \\
\hline $\begin{array}{l}\text { Chemical- } \\
\text { Hypoxia and } \\
\text { hypercapnia }\end{array}$ & $\begin{array}{l}\text { Relatively shallow } \\
\text { water, space needed for } \\
\text { bulk gas storage }\end{array}$ & $\begin{array}{l}\text { Based on chemicals that } \\
\text { decrease or increase the } \\
\text { water oxygen content }\end{array}$ & $\begin{array}{c}\text { It is possible to exclude } \\
\text { all fish }\end{array}$ & $\begin{array}{l}\text { Large capital investments } \\
\text { and research period }\end{array}$ \\
\hline $\begin{array}{l}\text { Chemical- } \\
\text { Chlorine }\end{array}$ & $\begin{array}{c}\text { Very limited } \\
\text { implementation area }\end{array}$ & $\begin{array}{l}\text { Based on the chlorine } \\
\text { entry in water }\end{array}$ & $\begin{array}{c}\text { May selectively exclude } \\
\text { all fish }\end{array}$ & $\begin{array}{c}\text { Dangerous to almost all } \\
\text { aquatic wildlife; negative } \\
\text { public perception }\end{array}$ \\
\hline Pheromones & $\begin{array}{c}\text { Small areas and/or } \\
\text { short-term applications }\end{array}$ & $\begin{array}{l}\text { Based on the entry of } \\
\text { pheromones in water }\end{array}$ & $\begin{array}{c}\text { May selectively exclude } \\
\text { certain fish }\end{array}$ & $\begin{array}{c}\text { Time and effort to purchase } \\
\text { pheromones in } \\
\text { bulk quantity }\end{array}$ \\
\hline Electromagnetism & $\begin{array}{l}\text { Narrow areas, narrow } \\
\text { spots }\end{array}$ & $\begin{array}{l}\text { Based on the use of } \\
\text { electromagnetism }\end{array}$ & $\begin{array}{c}\text { Cost-effective, low } \\
\text { environmental impact }\end{array}$ & $\begin{array}{c}\text { Might not work on all } \\
\text { teleost fish }\end{array}$ \\
\hline
\end{tabular}

Given that the present paper addresses the study of the behavioural barriers consisting of bubble curtains and aims to determine the influence of the curtain on the velocity field, below we present a brief description of the current state of research on the associated hydrodynamic field. Behavioural barriers consisting of bubble curtains are considered as a deterrent to fish movements in some experimental laboratory or in situ studies reported in literature $[20,28,47-49]$. The role of a bubble curtain barrier is to create a physical field that can be detected by fish; this determines a deterring response, making the fish avoid that area. Thus, the physical fields generated by a bubble curtain must be measured or characterised in detail in order to make a connection with the response of the fish. According to the study of Webb et al. [20], the hydrodynamic and acoustic field generated by a bubble curtain can guarantee a clear avoidance response from fish. Regarding the hydrodynamic field, the velocity fluctuations and the turbulence created by a bubble barrier are of interest; from an acoustic point of view, the sound pressure level (SPL) generated by the bubbles is analysed. Fish detect the velocity and sound fields by the lateral line (a sensory organ that detects the movements and vibrations in the water, and which helps species to avoid collision, to locate prey) and by the auditory system (inner ear). The lateral lines detect the movement of particles and the inner ear the pressure fluctuations. Experimental data reported by Zielinski et al. 2019 [28] have shown that a coarse bubble curtain creates a lower velocity field but a stronger acoustic field than a fine bubble curtain. Thus, in the research presented in our paper, it was decided to use fine bubbles, which create a higher velocity gradient.

Our own research [47] has shown that the bubble curtain generates a modified velocity field in the surrounding water, creating recirculation (Figure 1). 


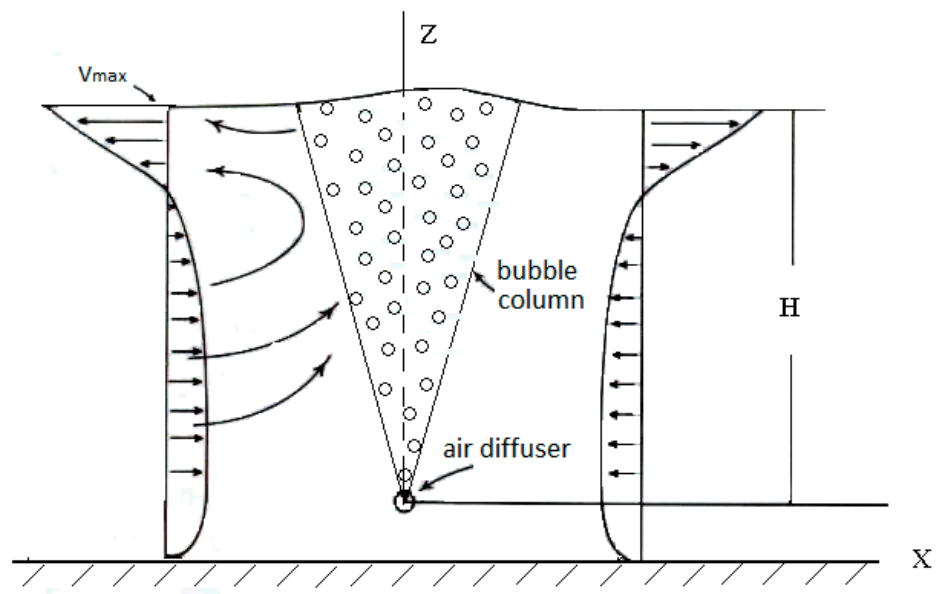

Figure 1. The flow induced in water by a bubble column, adapted from Oprina et al. [47].

In addition, the research of Brevik and Kristiansen [48] showed that the velocity field induced by the bubble column can be divided into two subcategories: the near field and the far field. The far field is dominated by a horizontal recirculation cell that extends a distance of about twice the depth, and the near field is dominated by the vertical velocity of the bubble curtain and occurs in the vicinity of the bubbles. The essential difference between the two velocity fields is given by the fact that in the far field, the maximum velocity is in the horizontal plane (along the flow), and in the near field, the maximum velocity is in the vertical plane (perpendicular to the flow). This creates a sharp velocity gradient. Assuming that fish are swimming at some distance from the bubble curtain and moving from the far field to the nearest field, they should be able to detect the velocity gradient and to be discouraged from passing through the bubble curtain.

Regardless of the implemented solutions' multiple advantages (protecting fish populations, maintaining biodiversity in the water stream, etc.), bubble curtains were also used to prevent fish entrapment in port areas, limit access of invasive species in different waters [22], and prevent the access of jellyfish in water supply catchments. In order to improve the efficiency of the guidance system combined solutions, behavioural barriers were used to guide the fish on a particular route. The research on bubble curtains was recently approached under research grants (2012), such as that in [49]. The study aimed at determining the characteristics of hydro-gas dynamics of fine and coarse bubble diffusers and the induced velocity at different operating conditions, emphasising the need of a thorough analysis of bubble curtains and flow spectrum. Recent approaches of this type of technology demonstrates that there is a large interest worldwide on implementing this kind of eco-friendly systems in the benefit of water quality including aquatic fauna.

\section{Laboratory Testing of a Behavioural Barrier for Ecological Water Intakes}

In order to study the behavioural barrier for ecological water intakes, an experimental setup was designed and built envisaging the analysis of a hybrid system-ecological water intake operating in tandem with a bubble curtain.

In the field of water intake arrangements, few solutions stood the test of time, but these also have some shortcomings in terms of captured flow and fish protection (especially when ensuring migration condition by maintaining longitudinal connectivity). The widespread solution for mountain rivers is the Tyrolean intake, which recently started to be upgraded with Coandă screens with better performances. These constructions have complementary fish steps for ensuring migration, which often cannot operate due to several issues like insufficient flow through each step, high slope, clogging with debris, etc. Fish protection in the upstream section of the intake is very difficult because the bottom screen with large openings and high suction velocities acts like a perfect trap for the aquatic fauna present in the stream. The design and sizing of new types of intakes is based on considerations 
related to operation of existing facilities and aims to ensure both the water needs and the flow conditions of the river.

The ecological water intake is a new concept, that the authors have studied and improved over the last few years. Its main feature consists in keeping the longitudinal connectivity of the river so the fauna can move upstream and downstream without any obstacles. In addition, the intake is easy to be integrated in the surrounding environment, having minimal influence on the watercourse.

The water intake experimental setup consists of an intake chamber with perforated orifices which communicates through an inlet with a lower tank for discharging the flow captured from the main channel of the test stand; the lower tank is placed under the intake chamber, having the role of water storage and ensuring a gravitational flow of the water taken through an upper hole connected to that of the intake chamber. The water taken by the intake is recirculated through a water circuit provided with a pump and a flow meter that enables the measurement of the captured water flow rate. Schematic drawing of the experimental setup of the water intake and behavioural barrier is presented in Figure 2.

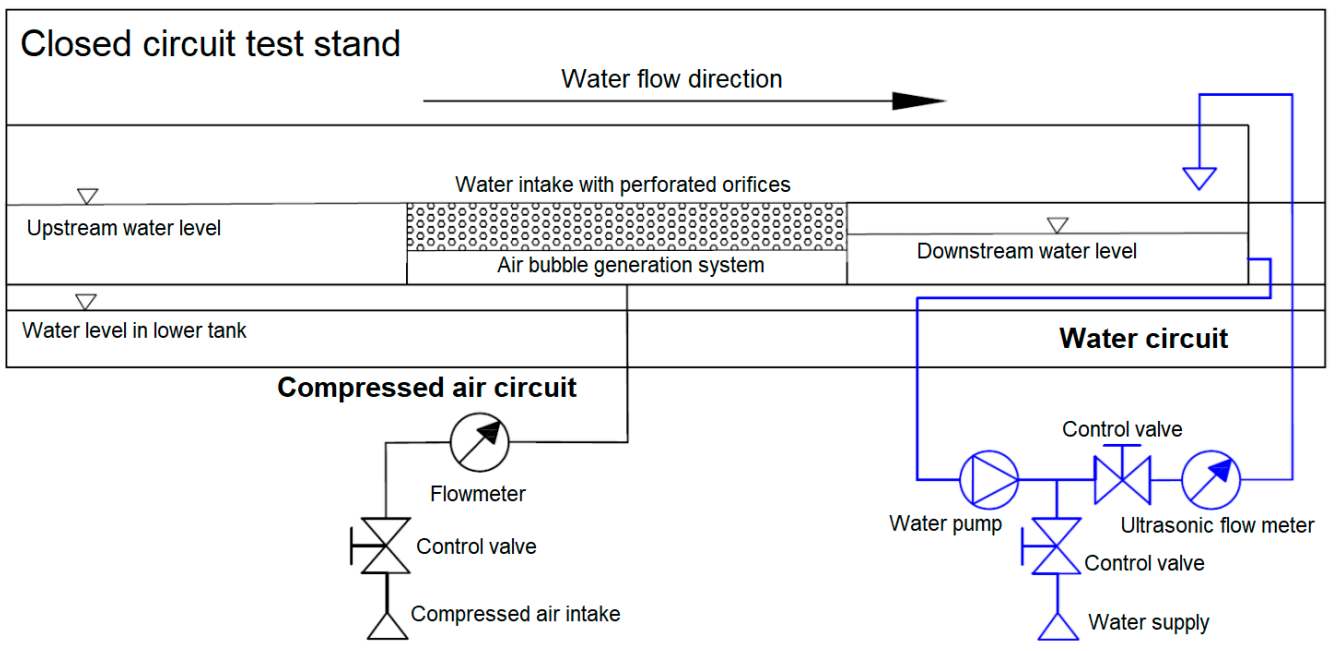

Figure 2. Schematic drawing of the experimental setup of the water intake and behavioural barrier.

For performing the tests, a perforated plate with $55 \mathrm{~mm}$ width and $400 \mathrm{~mm}$ length is used. It has 440 orifices with $4 \mathrm{~mm}$ diameter. Figure 3 shows details of the perforated surface of the intake. During the experiments, not all the 440 holes could be used because the tank below and the intake chamber are flooded and switched to suction operating conditions. Therefore, only the first rows at the top (with a number of 80 perforated holes) were used for the preliminary tests. Thus, a constant level could be maintained in the lower tank, ensuring gravitational flow.

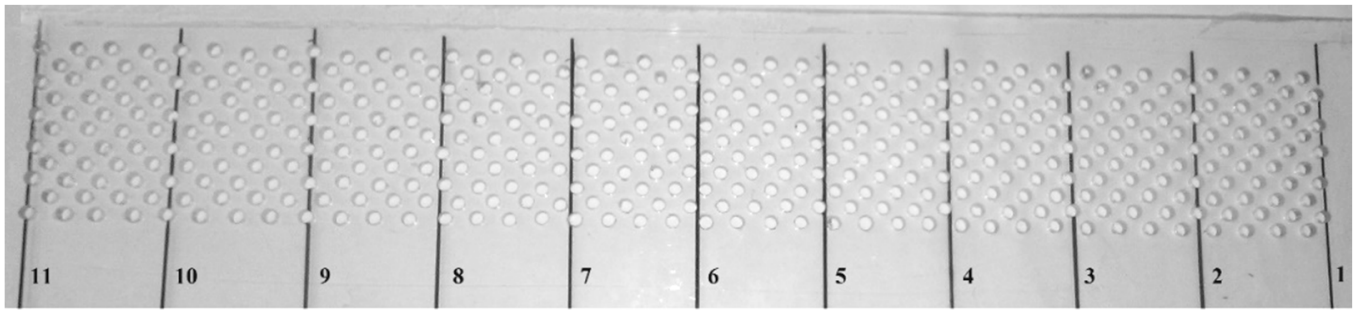

Figure 3. Detail on the perforated surface of the intake.

For the fish guidance system, an air bubble generation system was installed at the base of the intake chamber. We first tried ceramic diffusers, then a porous hose specially designed for aerating fishponds. Better results have been obtained with the porous hose that is widely used in water aeration applications (Tanuki Japanese hose). The air bubble generation system is connected to a compressor for supplying compressed air. A precision 
valve for regulating the flow rate and a flowmeter for measuring its value are installed in the compressed air circuit. The two main components of the hybrid system under study, a behavioural barrier of ecological water intake model, have been integrated in a closed-circuit hydraulic stand (Figure 4 ) provided with a transparent visualisation area $(375 \times 300 \times 1015 \mathrm{~mm})$ made of Plexiglass (polymethyl methacrylate). The stand is a hydraulic unit made in a watertight and removable modular construction, which circulates clean water in a closed circuit. The main modules of the stand are represented by test section, tank, recirculation pumps, and variable speed motors. The closed-circuit hydraulic stand has a system for measuring and controlling the water flow and velocity in the channel and an acquisition and processing system as well. Thus, it allows water flow velocity adjustment to provide velocities between $0.05 \mathrm{~m} / \mathrm{s}$ and $1 \mathrm{~m} / \mathrm{s}$ in the test section.

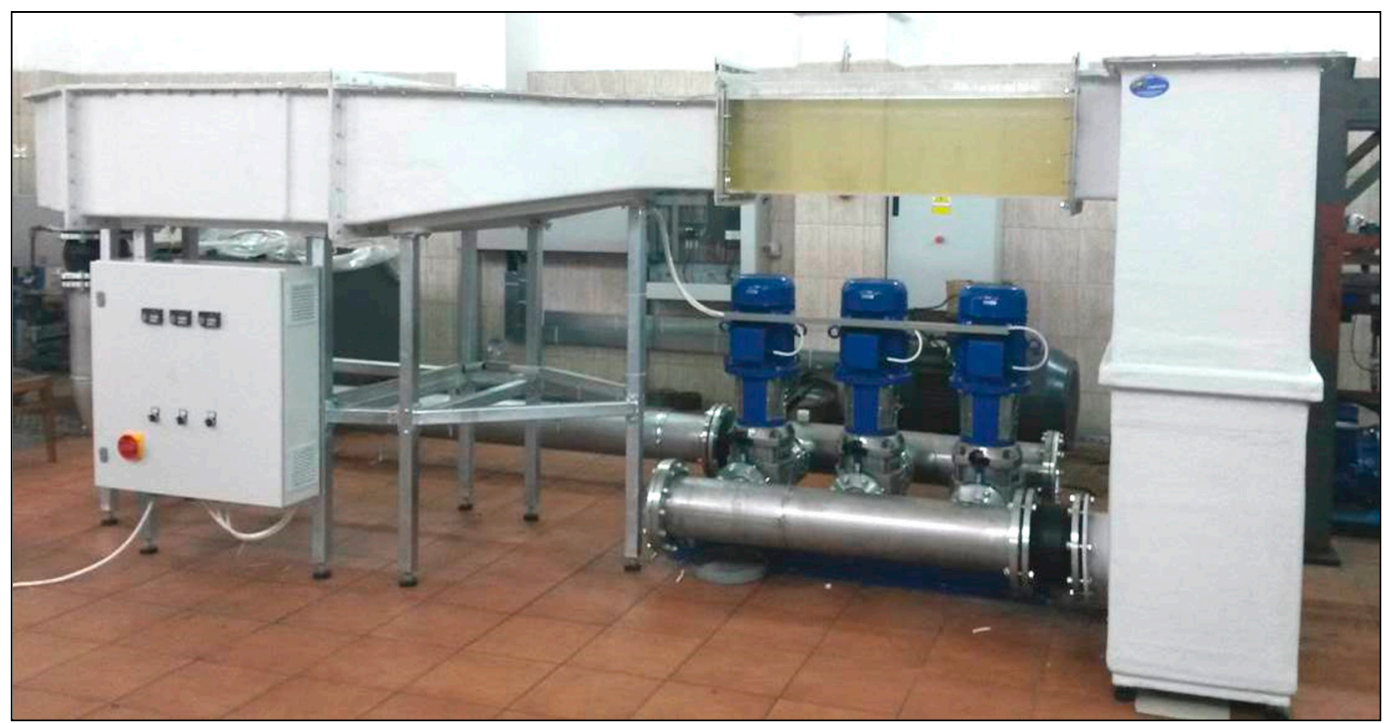

Figure 4. Closed circuit hydraulic stand.

For the experimental model of hybrid ecological intake with behavioural barrier testing, a part of the data acquisition system related to water velocity measurement was used. The water velocity was measured with a Pitot-Prandtl tube positioned in water in parallel direction to the flow. As shown in Figure 5, the tube is fixed by a system that allows sliding horizontally and vertically at certain marked positions detailed in Figure 6.

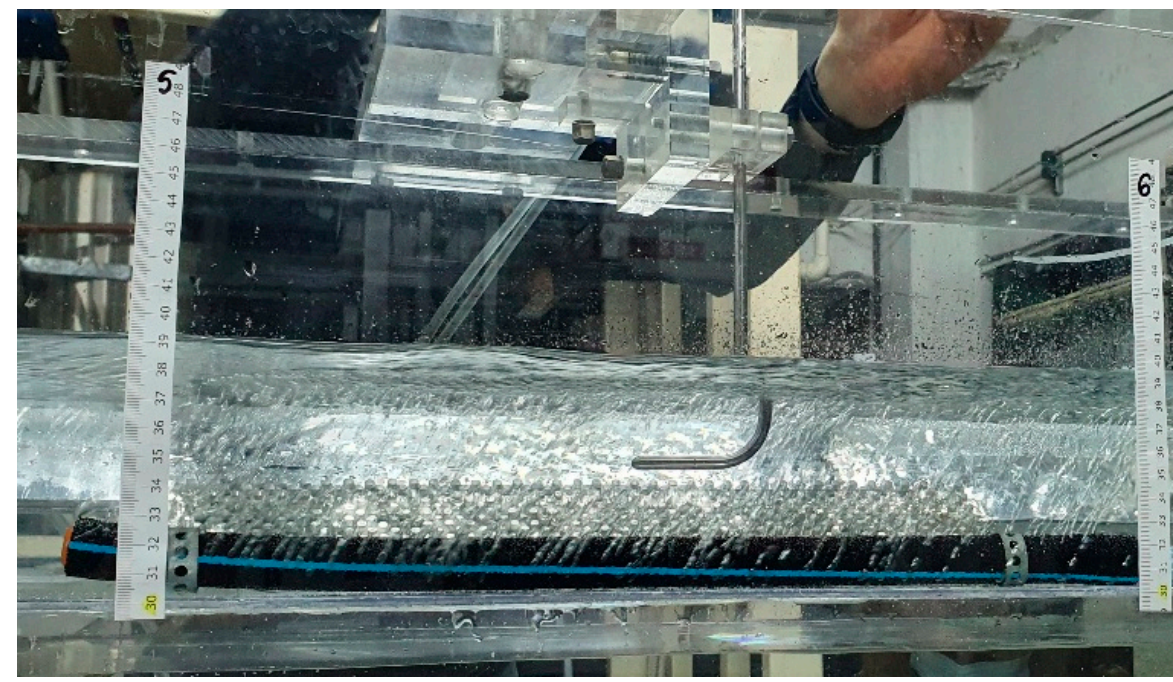

Figure 5. Details on Pitot-Prandtl tube position for measuring water velocity. 


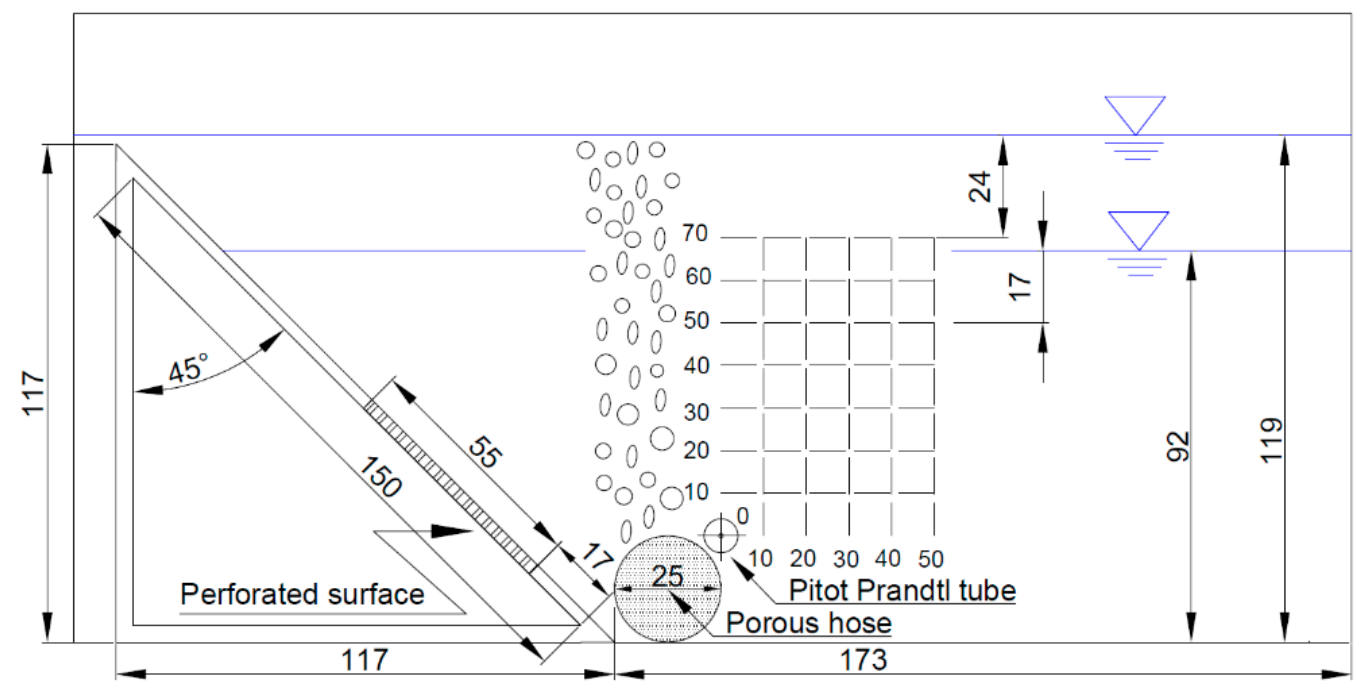

Figure 6. Position of the velocity measuring points for two different water depths in the channel.

In order to perform the necessary tests, the pump group converters are started and the required velocity in the experimental stand channel is established before performing the velocity measurements using the Pitot tube. Water levels are measured in all enclosures (intake chamber upstream, downstream and in the drainage area, as well as the lower reservoir level). The water flow rate through the water intake model is measured using an Axioma smart ultrasonic flowmeter, model Qalcosonic W1. The air flow rate through the bubble diffuser is measured using a Cole Parmer flowmeter with a 0 to 20 LPM scale, with an accuracy of $\pm 5 \%$ of full scale. The water velocity for each point shown in Figure 6 is measured by the Pitot tube which is connected to a differential pressure transducer model AppliSens, type APRE-2000 with accuracy $\pm 0.1 \%$ of calibrated range -5 to 70 mbar. For $92 \mathrm{~mm}$ water depth, the velocity was measured in 36 points (from 0 to 50 in horizontal and vertical directions), while for $119 \mathrm{~mm}$ water depth the velocity was measured in 42 points (from 0 to 50 in horizontal direction and from 0 to 70 in vertical direction, respectively).

In the Figure 7 the experimental setup of the water intake and behavioural barrier is presented from opposite views. The transparent viewing section allows the phenomena observation and water level measurements. On top of the experimental setup, the PitotPrandtl tube slides across the measuring points.

Figure 8 shows that a higher velocity in the main channel determines an increase in the turbulence, especially in the free surface area.

The assessment of the bubble curtain influence on the water flow inside the channel was made by analysing the velocity variation in vertical direction, where certain dependencies between air flow rate, water depth, and velocity have been found.

The bubble curtain influence on the water velocity was investigated for two water depths $(\mathrm{H}=92 \mathrm{~mm}$ and $\mathrm{H}=119 \mathrm{~mm})$, two water velocities inside the channel $(0.33 \mathrm{~m} / \mathrm{s}$ and $0.535 \mathrm{~m} / \mathrm{s})$, and two air flow rates (10.5 LPM and 15 LPM). The velocities were compared with the case where no air was injected (0 LPM) in order to determine the bubble curtain influence on the water flow. The water velocity inside the transparent channel of the experimental setup was chosen to vary between $0.33 \mathrm{~m} / \mathrm{s}$ and $0.535 \mathrm{~m} / \mathrm{s}$ to cover the typical water velocities of most mountain rivers [50]. A summary of the testing conditions of the hybrid solution model of ecological river water intake with bubble curtain behavioural barrier is presented in Table 2. 
a)

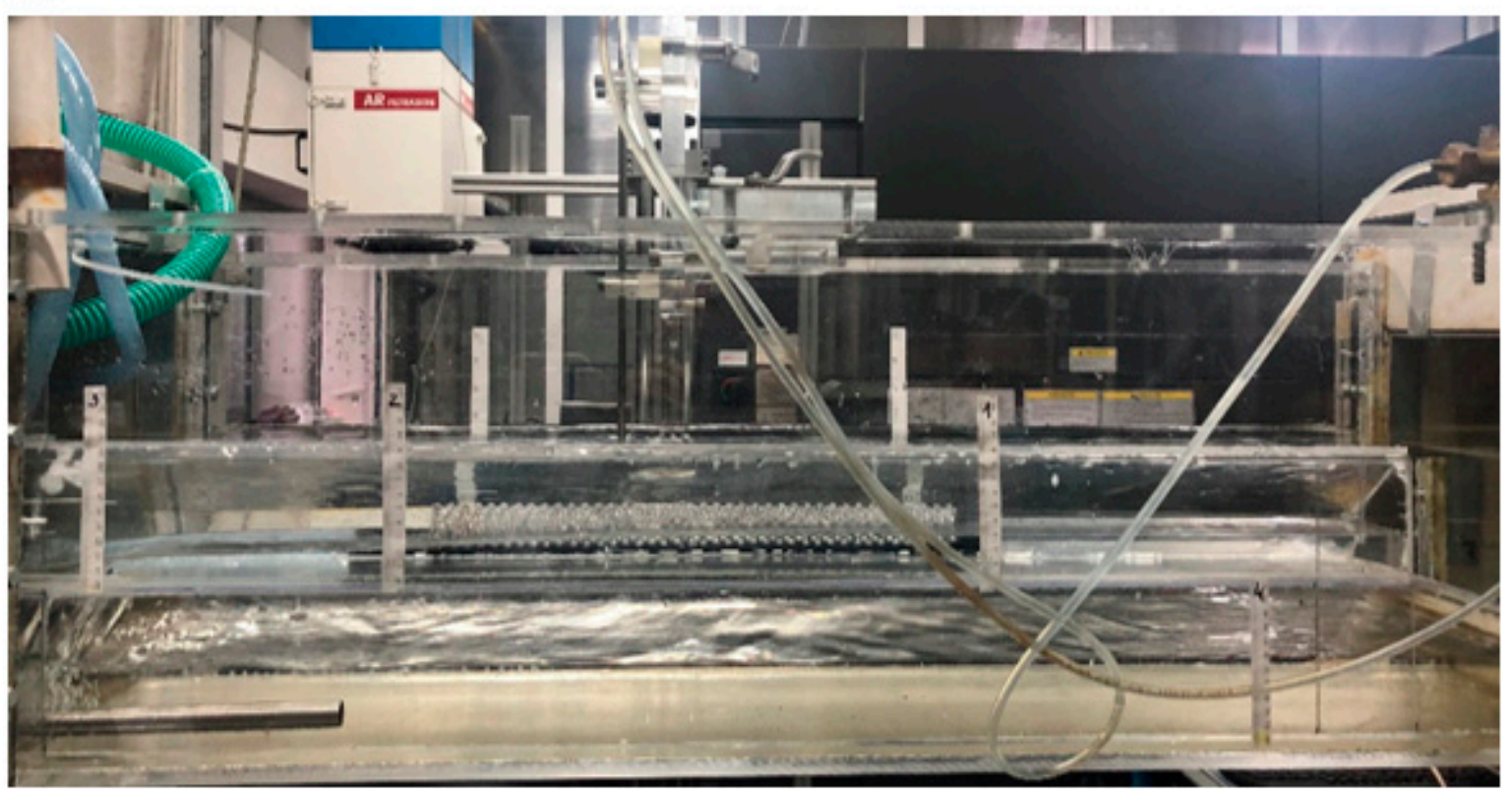

b)

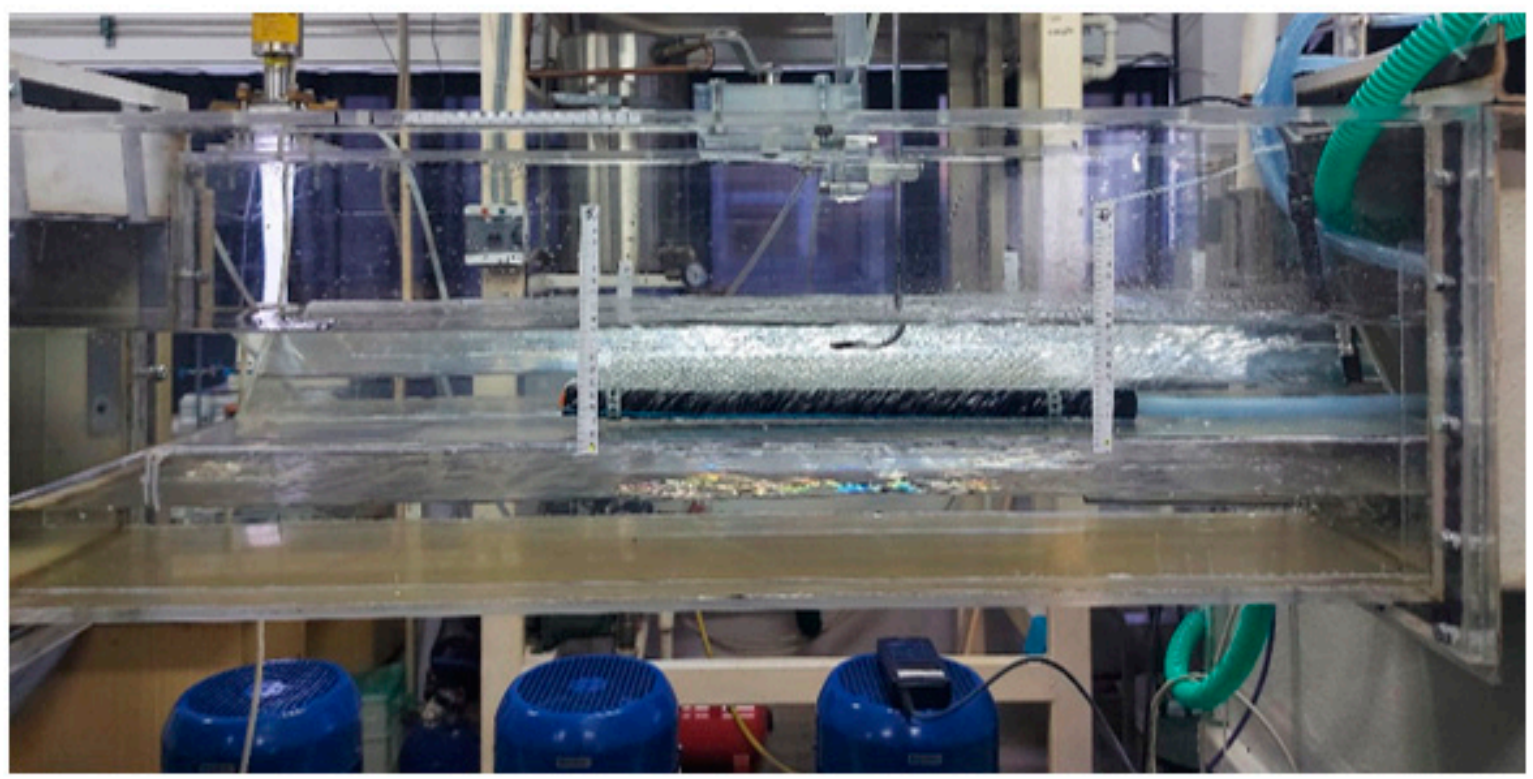

Figure 7. Images of the experimental setup of the water intake and behavioural barrier: (a) Left side view; (b) right side view.

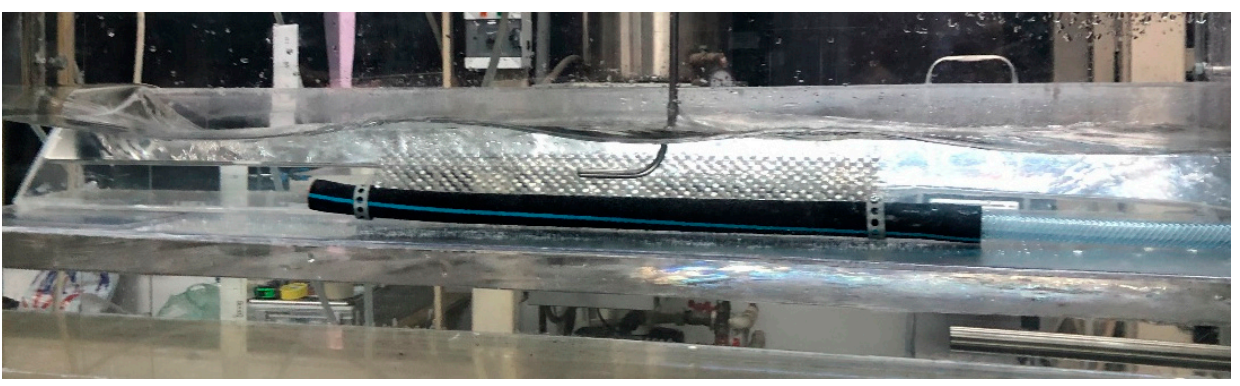

Figure 8. Detail on free surface turbulence for $\mathrm{v}=0.535 \mathrm{~m} / \mathrm{s}$ and $\mathrm{H}=119 \mathrm{~mm}$. 
Table 2. Water depths, velocities, and airflow rates used for testing the hybrid solution model.

\begin{tabular}{cccc}
\hline $\mathbf{v}_{\text {channel }}[\mathbf{m} / \mathbf{s}]$ & $\mathbf{H}[\mathbf{m m}]$ & $\mathbf{Q}[\mathbf{L P M}]$ & Figure \\
\hline 0.33 & 92 & 0 & 9 \\
\hline 0.33 & 92 & 10.5 & 10 \\
\hline 0.33 & 92 & 15 & 15 \\
\hline 0.535 & 92 & 0 & 11 \\
\hline 0.535 & 92 & 10.5 & 12 \\
\hline 0.535 & 92 & 15 & 16 \\
\hline 0.535 & 119 & 0 & 13 \\
\hline 0.535 & 119 & 10.5 & 14 \\
\hline 0.535 & 119 & 15 & 17 \\
\hline
\end{tabular}

\section{Results and Discussion}

The velocity variation in the horizontal direction is not significant as the bubbles are generated in vertical plane and they travel to the free surface with reduced lateral movements. This behaviour is beneficial because the bubble curtain is maintained parallel to the water intake area. The experiment showed that the water flow through the channel slightly influences the bubbles trajectories, being carried downstream.

Based on the measurements results, the induced velocity variation curves shown in Figures $9-17$ were drafted. The velocity induced in water by the bubble column was denoted by $\mathrm{v}$, the initial velocity in the channel by $\mathrm{v}_{\text {channel, }}$, the air flow rate by $\mathrm{Q}$, and the vertical and horizontal distance from the origin of the chosen coordinate system to the velocity measuring point by $\mathrm{Dv}$ and $\mathrm{Dh}$, respectively.

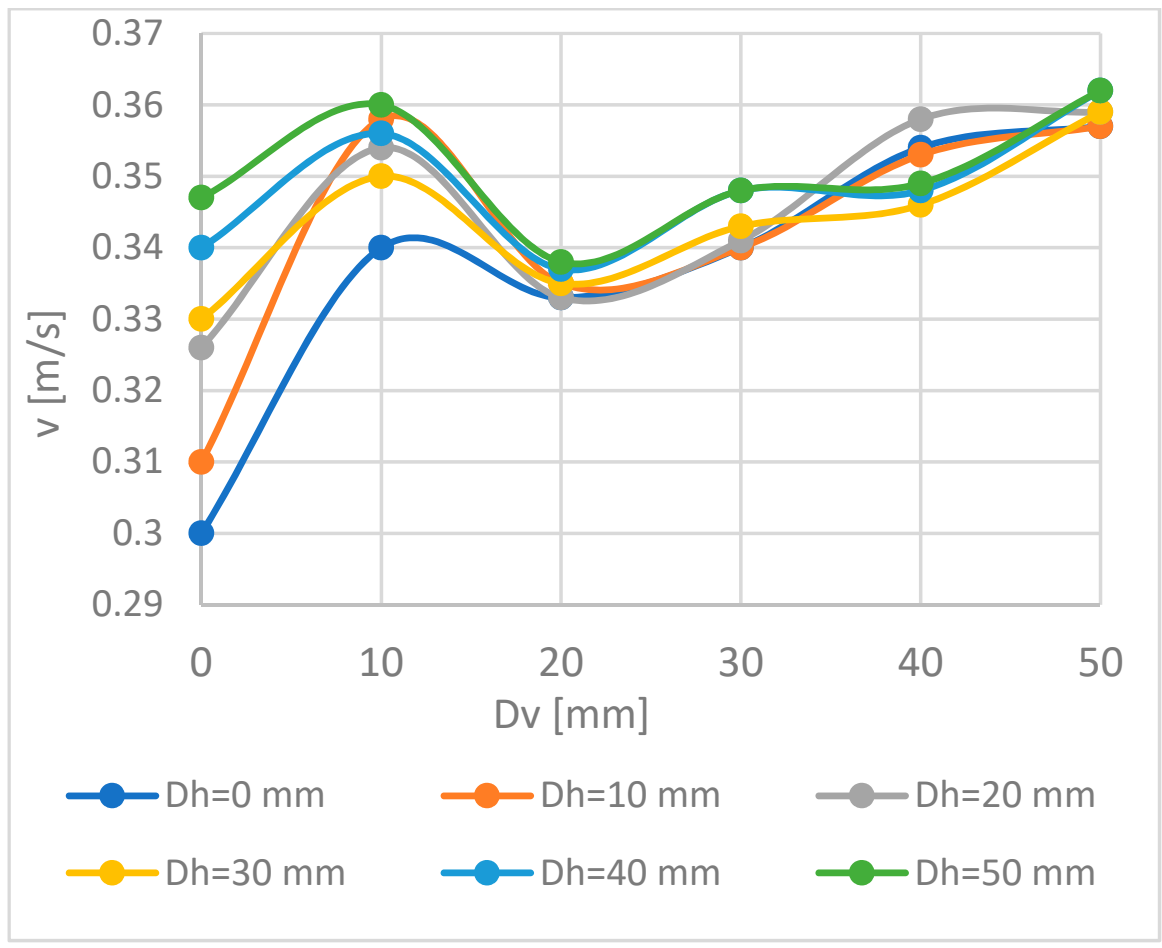

Figure 9. Induced velocity variation for $\mathrm{v}_{\text {channel }}=0.33 \mathrm{~m} / \mathrm{s}, \mathrm{Q}=0 \mathrm{LPM}, \mathrm{H}=92 \mathrm{~mm}$. 


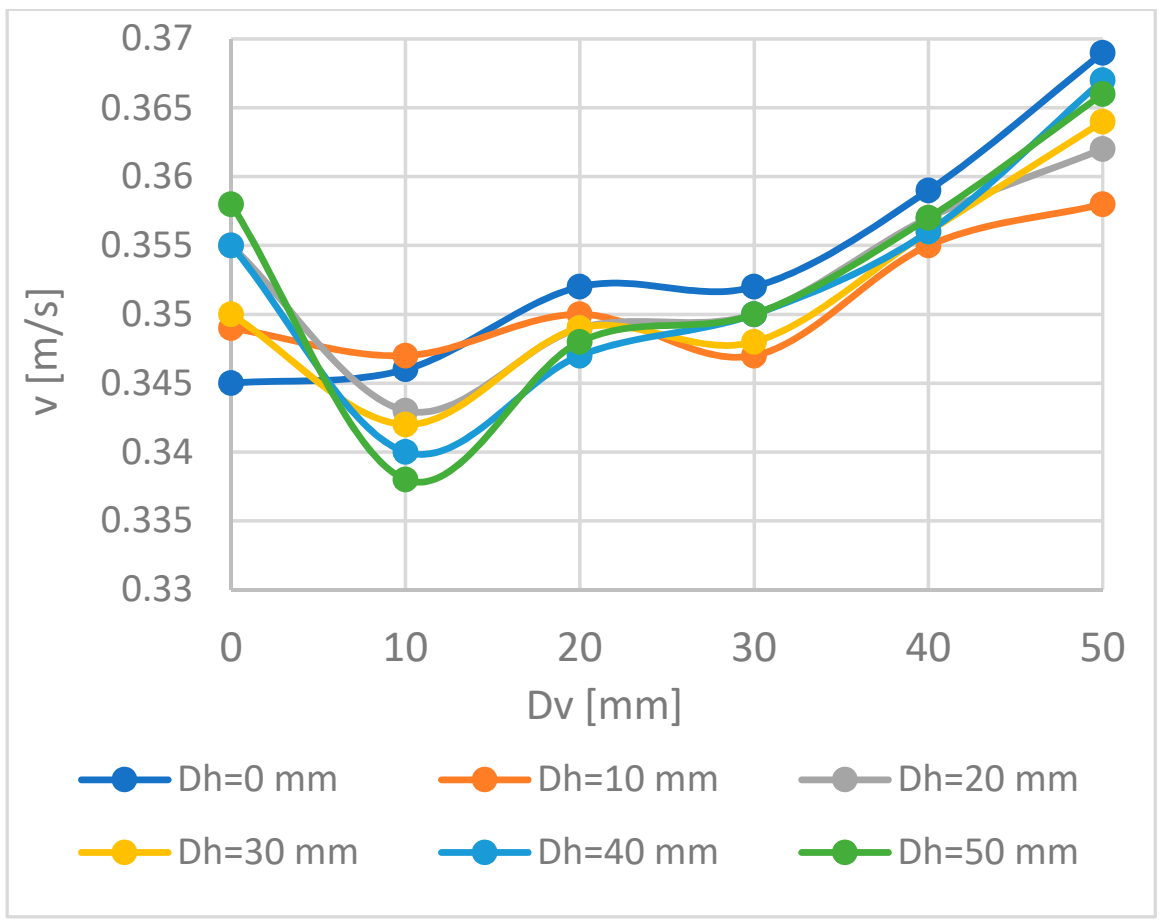

Figure 10. Induced velocity variation for $\mathrm{v}_{\text {channel }}=0.33 \mathrm{~m} / \mathrm{s}, \mathrm{Q}=10.5 \mathrm{LPM}, \mathrm{H}=92 \mathrm{~mm}$.

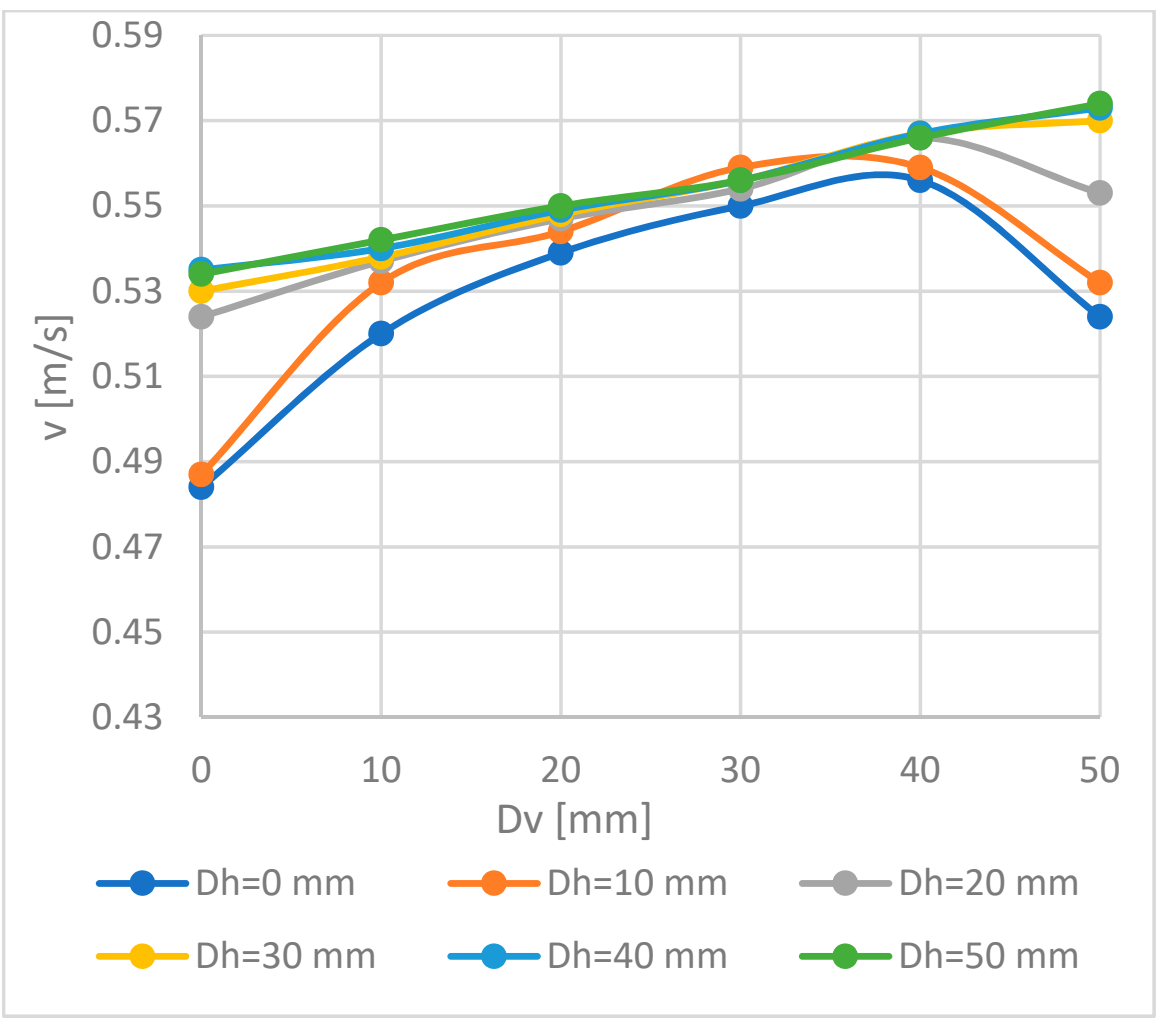

Figure 11. Induced velocity variation for $\mathrm{v}_{\text {channel }}=0.535 \mathrm{~m} / \mathrm{s}, \mathrm{Q}=0 \mathrm{LPM}, \mathrm{H}=92 \mathrm{~mm}$. 


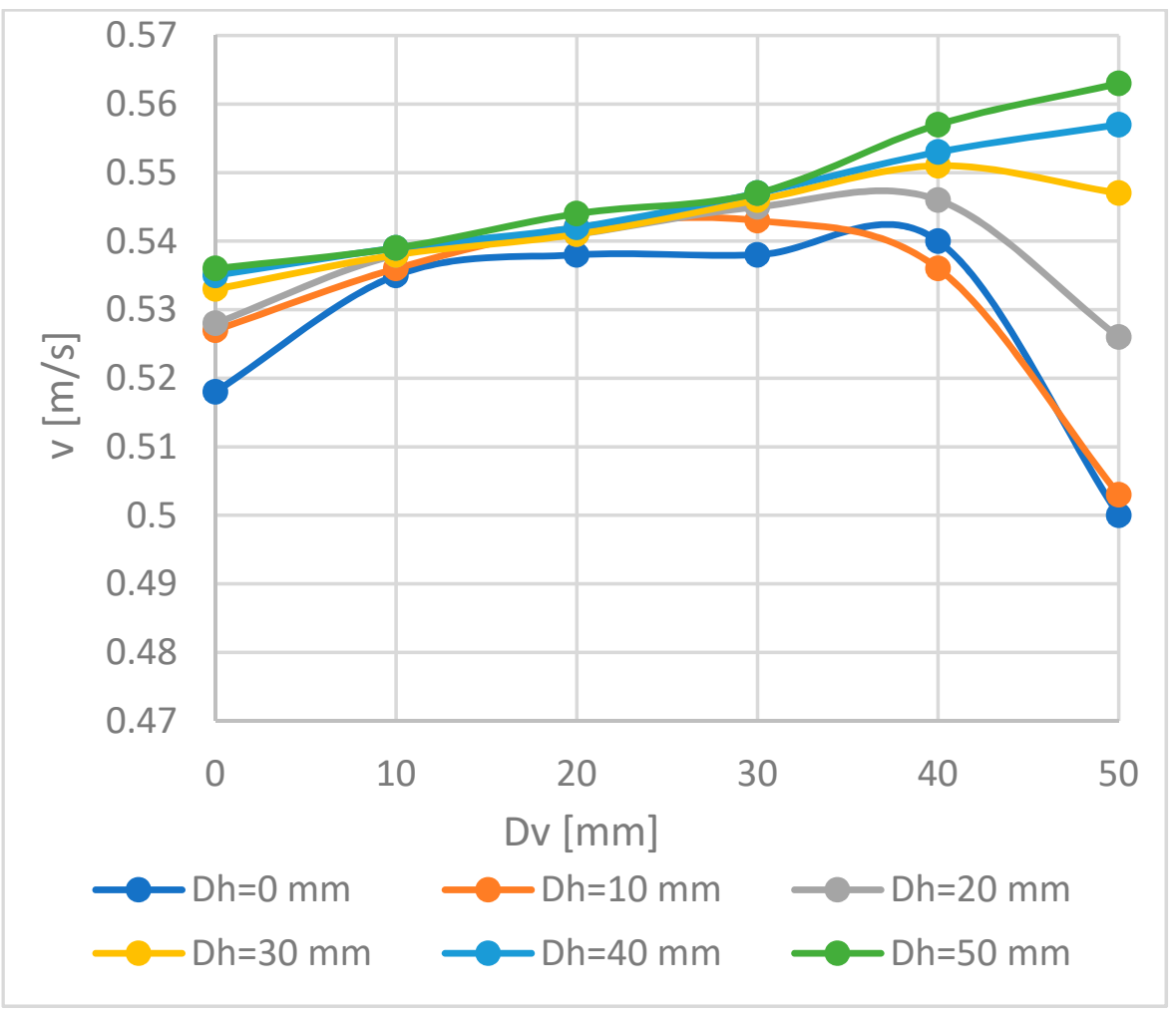

Figure 12. Induced velocity variation for $\mathrm{v}_{\text {channel }}=0.535 \mathrm{~m} / \mathrm{s}, \mathrm{Q}=10.5 \mathrm{LPM}, \mathrm{H}=92 \mathrm{~mm}$.

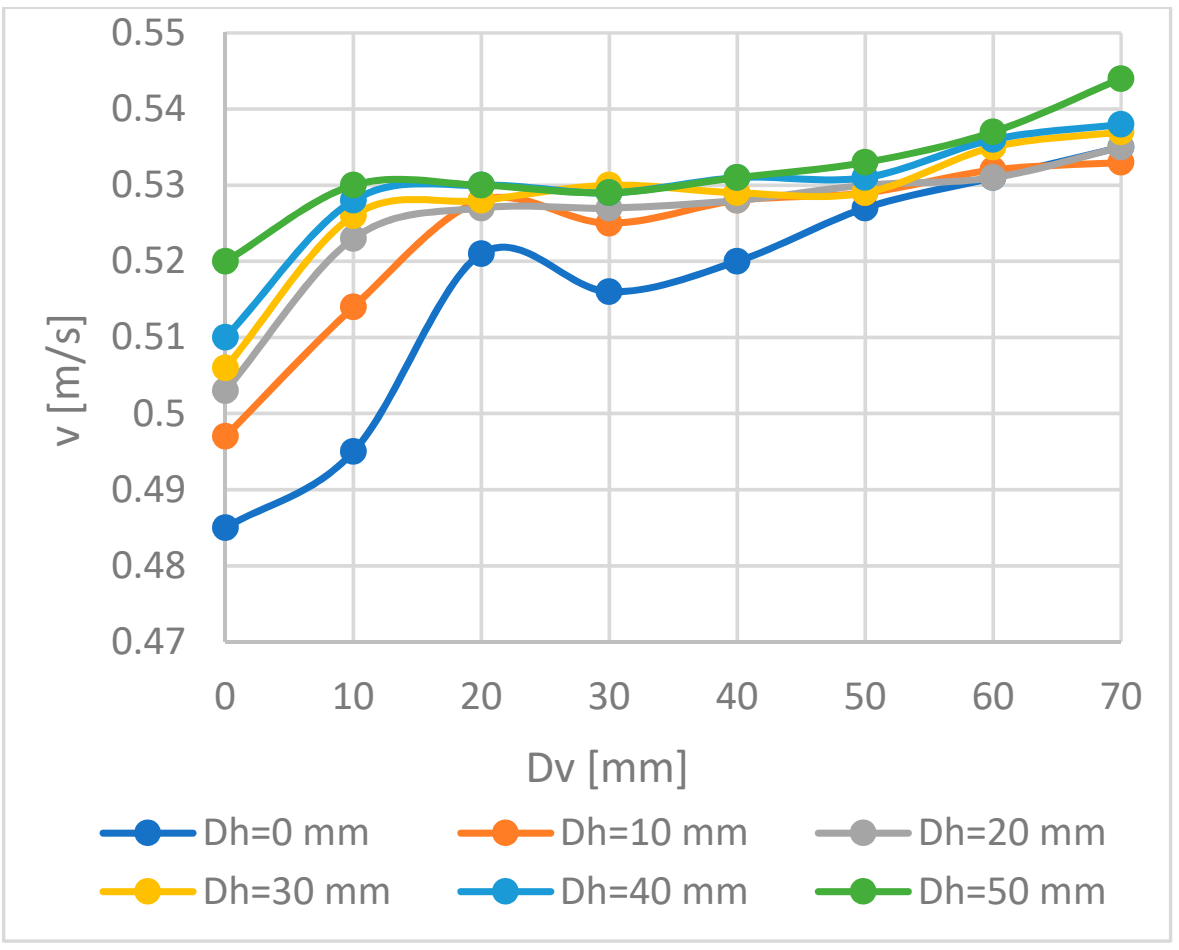

Figure 13. Induced velocity variation for $\mathrm{v}_{\text {channel }}=0.535 \mathrm{~m} / \mathrm{s}, \mathrm{Q}=0 \mathrm{LPM}, \mathrm{H}=119 \mathrm{~mm}$. 


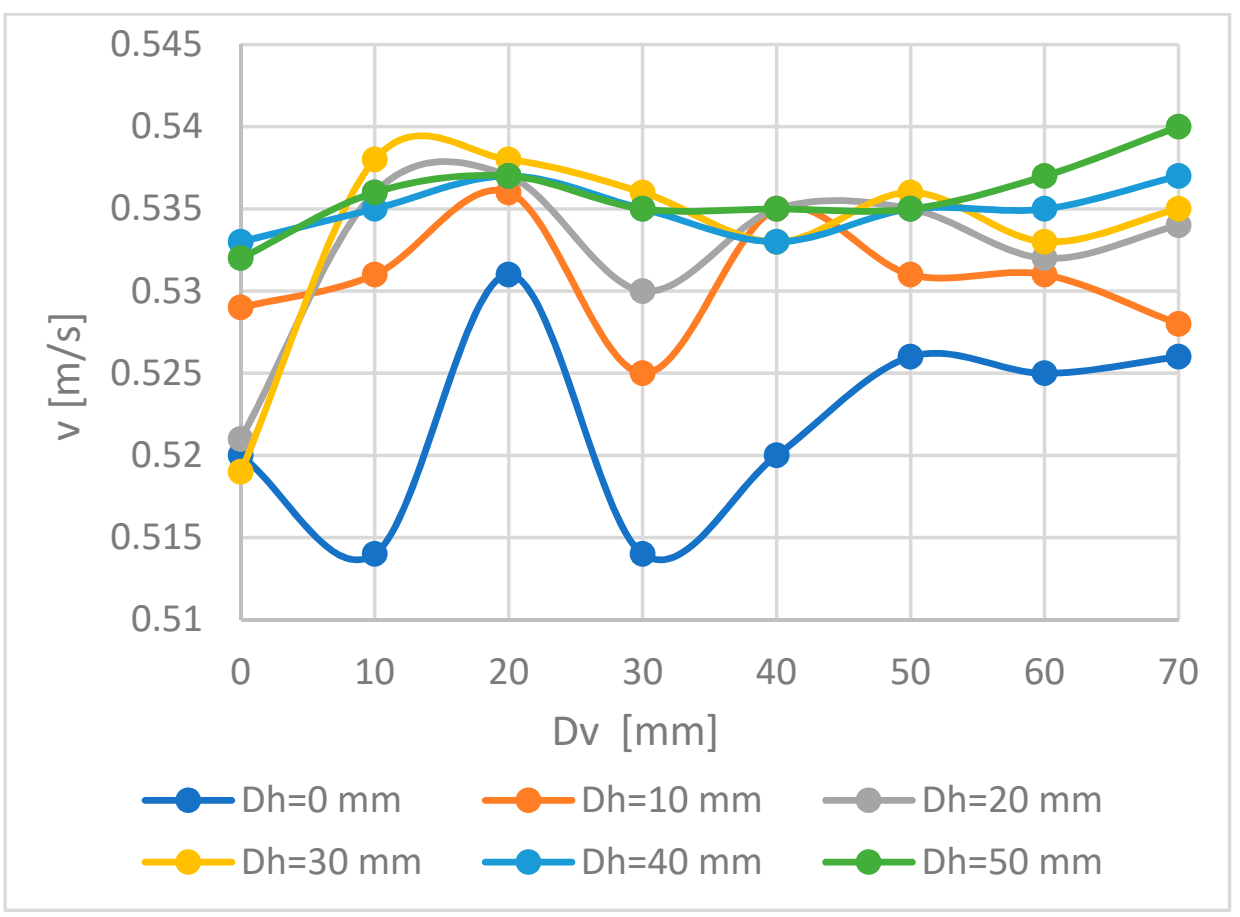

Figure 14. Induced velocity variation for $\mathrm{v}_{\text {channel }}=0.535 \mathrm{~m} / \mathrm{s}, \mathrm{Q}=10.5 \mathrm{LPM}, \mathrm{H}=119 \mathrm{~mm}$.

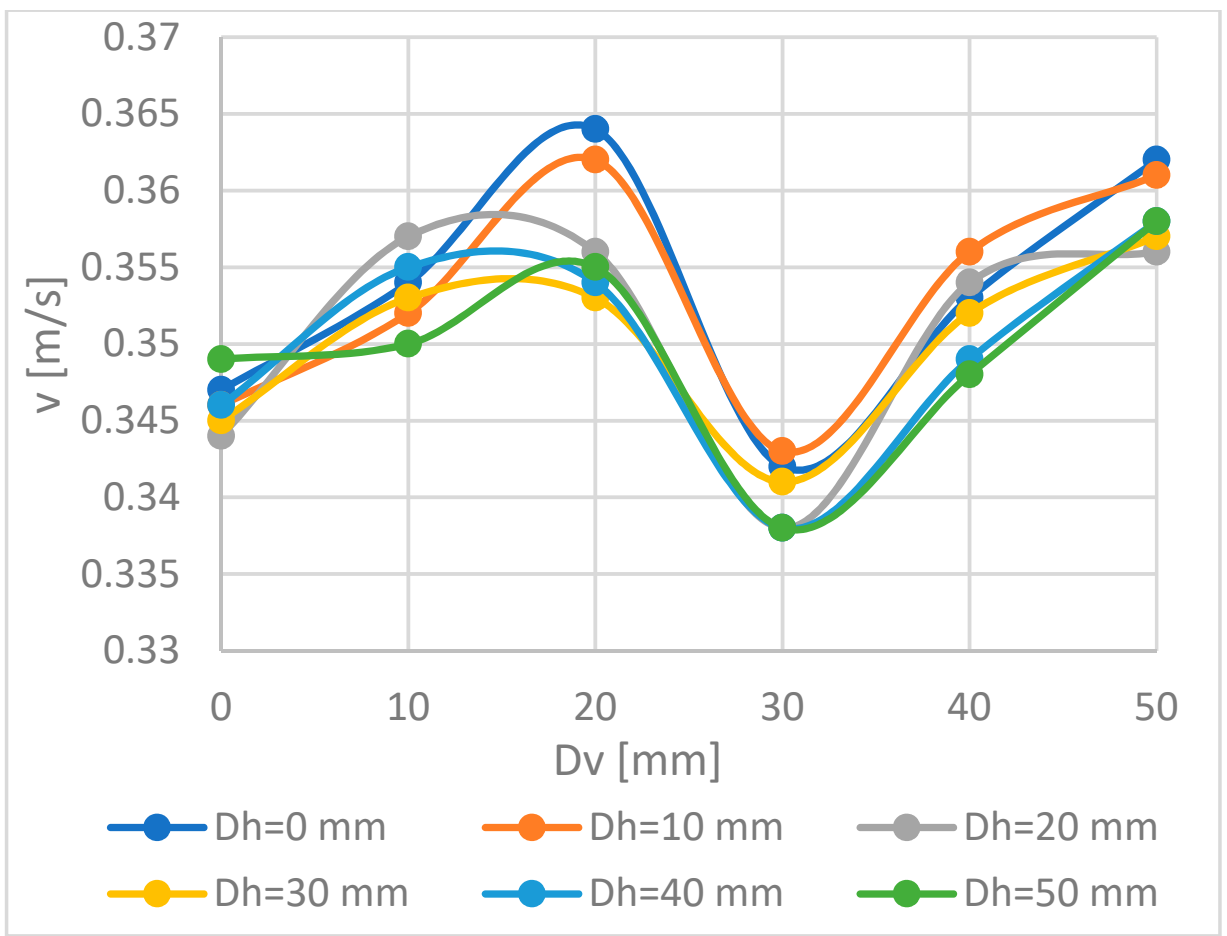

Figure 15. Induced velocity variation for $\mathrm{v}_{\text {channel }}=0.33 \mathrm{~m} / \mathrm{s}, \mathrm{Q}=15 \mathrm{LPM}, \mathrm{H}=92 \mathrm{~mm}$. 


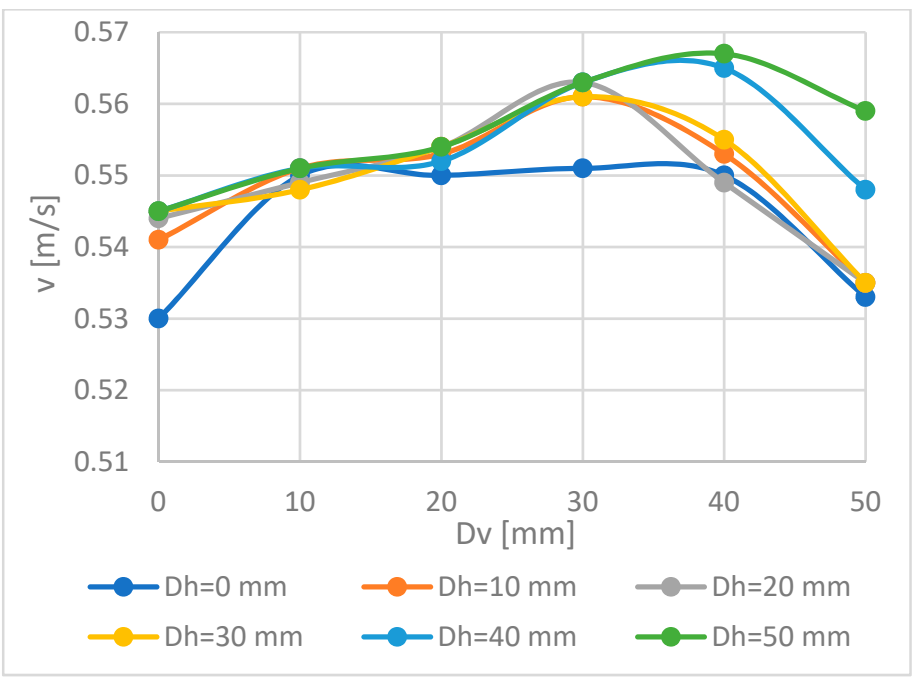

Figure 16. Induced velocity variation for $\mathrm{v}_{\text {channel }}=0.535 \mathrm{~m} / \mathrm{s}, \mathrm{Q}=15 \mathrm{LPM}, \mathrm{H}=92 \mathrm{~mm}$.

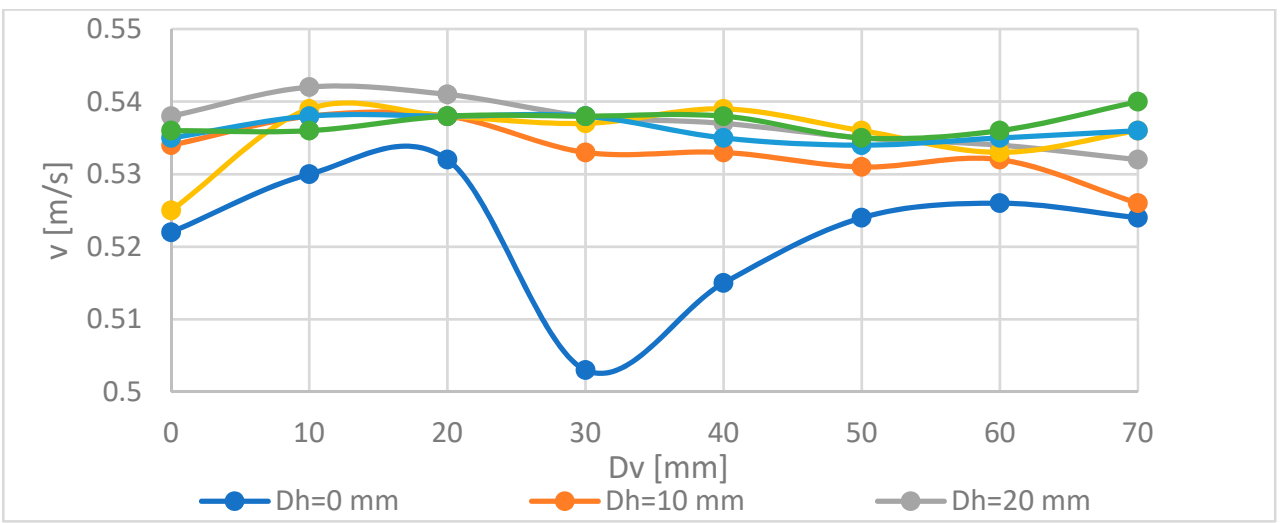

Figure 17. Induced velocity variation for $\mathrm{v}_{\text {channel }}=0.535 \mathrm{~m} / \mathrm{s}, \mathrm{Q}=15 \mathrm{LPM}, \mathrm{H}=119 \mathrm{~mm}$.

For the case of $0.33 \mathrm{~m} / \mathrm{s}$ water velocity in the main channel and $92 \mathrm{~mm}$ depth (Figures 9, 10 and 15), the gap between the velocity variation on each vertical is smaller than in the $0.535 \mathrm{~m} / \mathrm{s}$ velocity case; there is an increasing tendency of the gap as it approaches the free surface. Furthermore, the increase of the air flow favours the increase of the velocity gradient for the $0,10,20$, and $30 \mathrm{~mm}$ verticals.

For $0.535 \mathrm{~m} / \mathrm{s}$ velocity and $92 \mathrm{~mm}$ depth (Figures 11, 12 and 16) case, the higher velocity in the main channel determines a turbulence increase, especially in the free surface area. Thus, in the $40 \mathrm{~mm}$ and $50 \mathrm{~mm}$ verticals area, there is a decrease in velocity due to the proximity of the Pitot tube to the free surface $(17 \mathrm{~mm})$. On the other hand, when the water level in the channel increases to $119 \mathrm{~mm}$, the Pitot tube is placed at a greater depth from the free surface-24 $\mathrm{mm}$ respectively (at the point located in vertical direction at a distance of $70 \mathrm{~mm}$ from the porous hose), as shown in Figure 6. In this case, the influence of the free turbulence is reduced.

For $0.535 \mathrm{~m} / \mathrm{s}$ water velocity and $119 \mathrm{~mm}$ water depth, with no air flow injected (Figure 13), the sudden increase in the velocity starting with the 10 to $30 \mathrm{~mm}$ verticals is due to the disturbed water current in the catchment area of the intake. In vertical plane, the water intake area corresponds to the distance of 10-30 $\mathrm{mm}$.

When injecting air with a flow rate of 10.5 LPM and 15 LPM, respectively (Figures 14, 15 and 17), the velocity shows significant oscillations. Thus, the first three vertical sections located in the proximity of the bubble curtain $(0,10,20 \mathrm{~mm})$ show the largest oscillations; starting with the vertical of $30 \mathrm{~mm}$, the variation becomes uniform, which is explained by moving 
away from the bubble curtain and the reduction of its influence on the flow (practically, the induced flow by the bubble curtain is diminished).

In terms of the influence of the water catchment through the intake, we found that near the intake (at a vertical distance of 20-30 $\mathrm{mm}$ from the origin of the chosen coordinate system) the longitudinal velocities field (which should have increased towards the free surface) has a decrease due to the increase of the velocity transverse component determined by the lateral catchment of the water. According to Figures 9 and 13, when no air is injected, this influence is noticed both in the low depth $(92 \mathrm{~mm})$ and low velocity $(0.33 \mathrm{~m} / \mathrm{s})$ case, as well as in the high depth $(119 \mathrm{~mm})$ and high velocity $(0.535 \mathrm{~m} / \mathrm{s})$ case. Starting with a distance of $30-40 \mathrm{~mm}$ (an average relative depth of 0.33-0.35) upwards, it is found that the longitudinal velocities are no longer influenced by the presence of the intake.

The introduction of air determines in the reduced water depth $(92 \mathrm{~mm}) /$ reduced velocity $(0.33 \mathrm{~m} / \mathrm{s})$ case, an increase of the longitudinal velocities field in the vicinity of the intake inlet $(15-30 \mathrm{~mm})$ area until a relative depth of 0.33 . With the increase of the air flow rate, the movement of the minimum longitudinal velocities towards the free surface is noticed.

We concluded that the generation of a bubble curtain near the intake causes a local modification in the water velocity field. This change also occurs at the introduction of a reduced air flow rate (10.5 LPM), showing that a bubble curtain can be efficient even for reduced air flow rates. Moreover, this effect can be maintained even when the water velocity increases from $0.33 \mathrm{~m} / \mathrm{s}$ to $0.535 \mathrm{~m} / \mathrm{s}$ (an increase of approximately $60 \%$ ). For increased water velocities, the bubble curtain is carried away downstream. Thus, the position of the bubble diffuser should be reconsidered. For increased velocities, the bubble diffuser must be placed with an offset of few centimetres upstream the river water intake. The bubble plume develops more effectively when the water depth is higher. As a general recommendation for real operating conditions, the diffuser should be placed as low as possible in the riverbed in order to benefit of a higher river depth.

In relation to the studies available in the literature, the experiments conducted in the present paper have shown that the bubble curtain generates a modified velocity field in the surrounding water, creating recirculation. The results are encouraging in relation with the findings reported in [48], where it is stated that the fish behaviour can be influenced by this sharp velocity gradient. Unlike the studies in the literature, the present research analysed the changes in the velocity profile under different study conditions. Thus, the water velocity profiles were experimentally determined both at different water depths and at different water flow rates in the testing channel, as well as at different air flow rates injected through the air hose generating the bubble curtain. In addition, the study was conducted on a small-scale hybrid experimental model that incorporates both an ecological river water intake that does not influence river morphology and a fish guidance system based on behavioural barriers; not only the operation of the river water intake model was investigated, but also the tandem operation of the hybrid model components. The water velocity variations induced by the bubble curtain is of interest as, according to the study performed by Mogdans in [50], the lateral-line component of the fish sensory system consists of superficial (hair cell) and canal neuromasts which practically are velocity and pressure gradient detectors respectively, placed on the fish body. They give fish neurological responses to hydrodynamic stimuli of the water due to their own movement, water waves, vortex recirculation, or sounds from air bubble breakup or abiotic sources. As seen from Figures 9-17, longitudinal flow velocity varies with each 10-20 mm cross-channel distance at increasing air flow rate for the same depth. This means that different water velocities may be sensed by the fish either along its body or on its left/right sides. Additionally, the lateral-line and inner ear are sensitive to acoustic underwater sounds up to $100-200 \mathrm{~Hz}$, as reported by Popper and Schilt [51], whereas, according to Braun et al. [52], in fish possessing a swimbladder, hearing is enhanced up to $1000 \mathrm{~Hz}$, which is close to the air bubbles splitting noise analysed by Frizell and Arndt [53]. Both hydrodynamic and sound stimuli give the central neurological system of the fish a signal of dangerous environment and force it to 
swim away. Given these findings [50-53], we consider that the current paper may contribute to the further understanding of the fish behaviour in relation with bubble curtains. In order to validate the conclusions drawn from the performed studies, the research shall continue with the inclusion of a biotic model. The present research was conducted in the frame of a project which did not consider animal testing for professional ethics reasons, and it focused on other scientific means to demonstrate the system functionality. Biotic model inclusion has not been taken into account yet because the research activity was performed on a state-of-the-art dedicated test stand that can accurately measure velocity fields (including PIV measurements) and other parameters, which can provide reliable results for the preliminary experimental validation of the hybrid solution-ecological intake with behavioural barrier. After this laboratory stage, an installation can be deployed in situ in order to study the interaction of the fish with the bubble curtain in real operating conditions. In this case, special attention will be given when designing the in situ facility in order not to harm the fish.

\section{Conclusions}

The research presented in the paper approached the experimental study of a fish guidance system consisted of a bubble curtain for a river water intake (perforated plate screen) to assess its influence on the water velocity field. In most of the analysed cases, a pronounced velocity gradient is observed in the proximity of the bubble curtain, confirming the hypotheses of previous studies [47,48], according to which the sharp velocity gradient can influence the behaviour of fish.

In addition, compared to traditional physical systems for fish guidance, the proposed behavioural barrier has the advantage to easily adapt to the flowing conditions of the river. Thus, by modifying the air flow rate of the diffusers, it results a bubble curtain characterised by another flow pattern: the bubble plume induces other velocities in the nearby water, the flow regime of the plume changes. Air flow regulation can be done from the river bank, without the need for intervention in the water, on site. If the change of the air flow rate is not enough, then the bubble diffusers can be replaced by other air generating system. To make this fish guidance system energy efficient, it is necessary to identify a minimum required air flow rate that will lead to an increase in local velocity near the intake. Taking into consideration that each fish species has specific characteristics, this solution must be adapted to the envisaged fish features.

During the performed tests, the influence of the water velocity due to the use of the bubble generation system was identified by measuring the water velocities in different points in the cross section of the experimental channel. The presence of the bubble curtain can act as a behavioural barrier for fish due to the modification of the velocity profiles in the considered area and to the sound pressure level. Moreover, by placing a bubble curtain in the admission proximity of the water intake where a suction effect is significant, the streamlines are modified, contributing to diverting this directional flow and deterring the fish from the intake area. Thus, alone or in combination with other behavioural barriers, the bubble curtain can contribute to the safe diversion of the fish into the downstream sector, considerably reducing the risk of accidental entrapment. An in-depth insight of this complex phenomena can be obtained by applying Particle Image Velocimetry measuring technique to determine the direction of the velocity vectors in the proximity of the bubble curtain and water intake.

Author Contributions: G.C. and R.-A.C., conceptualisation and methodology, G.C., R.-A.C., A.V. and L.-A.E.-L., writing-review and editing, A.V. and D.-E.G.N., literature review and investigation, S.-M.S. and L.M., formal analysis, G.C., R.-A.C. and A.V., investigation and data analysis, G.C., R.-A.C. and D.-E.G.N., results interpretation. All authors have read and agreed to the published version of the manuscript. 
Funding: This research was funded by Romanian Ministry of Education, Research and Digitalization, UEFISCDI, project number PN-III-P2-2.1-PED-2019-1444-Eco-hybrid Water Intake with Behavioral Barrier to Reduce the Impact on Fish Fauna and River Morphology.

Institutional Review Board Statement: Not applicable.

Informed Consent Statement: Not applicable.

Data Availability Statement: All data generated during the experiments and analysed in the current study are included in this published article.

Acknowledgments: This work was supported by the Romanian Ministry of Education, Research and Digitalization, UEFISCDI, project number PN-III-P2-2.1-PED-2019-1444-Eco-hybrid Water Intake with Behavioral Barrier to Reduce the Impact on Fish Fauna and River Morphology and project number 25PFE/30.12.2021 - Increasing R-D-I capacity for electrical engineering-specific materials and equipment with reference to electromobility and "green" technologies within PNCDI III, Programme 1.

Conflicts of Interest: The authors declare no conflict of interest.

\section{References}

1. Brasovanu, L.; Gogoașe Nistoran, D.E.; Armaș, I. The hydrological regime of the Prahova River along Carpathian and Subcarpathian stretch. GtaylorruebuseoPatterns 2018, 3, 32-42. [CrossRef]

2. The world's Biodiversity is Declining at an Alarming Rate. Population Sizes of Vertebrate Species Measured by the Living Planet Index (LPI) Have More than Halved in Little More than 40 Years. Available online: https:/ /wwf.panda.org/discover/ knowledge_hub/all_publications/living_planet_index2/ (accessed on 15 November 2021).

3. Äivas, L.; Kesminas, V. Fish distribution and ecological state of the Siesartis River, Lithuania. Acta Zool. Litu. 2011, $21,153-162$. [CrossRef]

4. Nijland, H.; Menke, U. Communication and Community Involvement: Lessons Learnt from SDF. In Proceedings of the Flood Risk Management and Multifunctional Land Use in River Catchments, Mainz, Germany, 17-19 October 2005.

5. Grill, G.; Lehner, B.; Lumsdon, A.E.; MacDonald, G.K.; Zarfl, C.; Reidy Liermann, C. An index-based framework for assessing patterns and trends in river fragmentation and flow regulation by global dams at multiple scales. Environ. Res. Lett. 2015, 10, 15001. [CrossRef]

6. Armaş, I.; Gogoaşe Nistoran, D.E.; Osaci-Costache, G.; Braşoveanu, L. Morpho-dynamic evolution patterns of Subcarpathian Prahova River (Romania). Catena 2013, 100, 83-99. [CrossRef]

7. Nistoran, D.G.; Ionescu, C.; Patru, G.; Armas, I.; Grigorie Omrani, S. One Dimensional Sediment Transport Model to Assess Channel Changes along Olteniţa-Cǎlăraşi Reach of Danube River, Romania. Energy Procedia 2017, 112, 67-74. [CrossRef]

8. Rodrigues, S.; Breheret, J.-G.; Macaire, J.-J.; Moatar, F.; Nistoran, D.; Juge, P. Flow and sediment dynamics in the vegetated secondary channels of an anabranching river: The Loire River (France). Sediment. Geol. 2006, 186, 89-109. [CrossRef]

9. Gogoaşe Nistoran, D.E.; Ionescu, C.S.; Brasoveanu, L.; Armas, I.; Opris, I.; Costinas, S. Modeling Hydrodynamic Changes Induced by Run-of-River Hydropower Plants along the Prahova River in Romania. J. Energy Eng. 2018, 144, 04017078. [CrossRef]

10. Nistoran-Gogoase, D.-E.; Brasoveanu, L.; Ionescu, C.-S.; Armas, I. Downstream coarsening of subsurface sediment grain size along upper Prahova River (Romania). GeoPatterns 2019, 4, 33-39. [CrossRef]

11. WWF-România. Analiza Legislaţiei Specifice din Domeniul Planificării şi Emiterii Actelor de Reglementare Aferente Construirii şi Funcţionării Microhidrocentralelor în RO; WWF: Bucharest, Romania, 2013.

12. Turnpenny, A.W.H.; O'Keeffe, N. Screening for Intakes and Outfalls: A Best Practice Guide; Science Report SC030231; Environment Agency: Bristol, UK, 2005; ISBN 1844323617.

13. U.S. Department of the Interior, Bureau of Reclamation. Fish Protection at Water Diversions-A Guide for Planning and Designing Fish Exclusion Facilities; U.S. Department of the Interior, Bureau of Reclamation: Denver, CO, USA, 2006.

14. Taft, E.P. Fish protection technologies: A status report. Environ. Sci. Policy 2000, 3, 349-359. [CrossRef]

15. Invasive Species. Available online: https://www.regions.noaa.gov/great-lakes/index.php/great_lakes-restoration-initiative/ invasive-species / (accessed on 10 January 2022).

16. Mills, E.L.; Leach, J.H.; Carlton, J.T.; Secor, C.L. Exotic Species and the Integrity of the Great Lakes. BioScience 1994, 44, 666-676. [CrossRef]

17. Noatch, M.R.; Suski, C.D. Review-Non-physical barriers to deter fish movements. Environ. Rev. 2012, 20, 71-82. [CrossRef]

18. Zielinski, D. Bubble Barrier Technologies for Common Carp. Master's Thesis, University of Minnesota, Minneapolis, MN, USA, 2011.

19. Taylor, R.M.; Pegg, M.A.; Chick, J.H. Response of bighead carp to a bioacoustic behavioural fish guidance system. Fish. Manag. Ecol. 2005, 12, 283-286. [CrossRef]

20. Webb, J.F.; Fay, R.R.; Popper, A.N. (Eds.) Fish Bioacoustics. In Springer Handbook of Auditory Research; Springer: New York, NY, USA, 2008; Volume 32. 
21. Hadderingh, R. Experimental reduction of fish impingement by artificial illumination at Bergum power station. Int. Rev. Ges. Hydrobiol. 1982, 67, 887-900.

22. Ruebush, B.C.; Sass, G.G.; Chick, J.H.; Stafford, J.D. In-situ tests of sound-bubble strobe light barrier technologies to prevent range expansions of Asian carp. In Proceedings of the 17th International Conference on Aquatic Invasive Species, San Diego, CA, USA, 29 August-2 September 2010; Volume 7, pp. 37-48. [CrossRef]

23. Dawson, H.A.; Reinhardt, U.G.; Savino, J.F. Use of Electric or Bubble Barriers to Limit the Movement of Eurasian Ruffe (Gymnocephalus cernuus). J. Great Lakes Res. 2006, 32, 40-49. [CrossRef]

24. Zielinski, D.P.; Sorensen, P.W. Bubble Curtain Deflection Screen Diverts the Movement of both Asian and Common Carp. N. Am. J. Fish. Manag. 2016, 36, 267-276. [CrossRef]

25. Zielinski, D.P.; Voller, V.R.; Svendsen, J.C.; Hondzo, M.; Mensinger, A.F.; Sorensen, P. Laboratory experiments demonstrate that bubble curtains can effectively inhibit movement of common carp. Ecol. Eng. 2014, 67, 95-103. [CrossRef]

26. Jesus, J.; Amorim, M.C.P.; Fonseca, P.J.; Teixeira, A.; Natário, S.; Carrola, J.; Varandas, S.; Pereira, L.T.; Cortes, R.M.V. Acoustic barriers as an acoustic deterrent for native potamodromous migratory fish species. J. Fish Biol. 2019, 95, 247-255. [CrossRef]

27. Leander, J.; Klaminder, J.; Hellström, G.; Jonsson, M. Bubble barriers to guide downstream migrating Atlantic salmon (Salmo salar): An evaluation using acoustic telemetry. Ecol. Eng. 2021, 160, 106141. [CrossRef]

28. Zielinski, D.P.; McLaughlin, R.; Castro-Santos, T.; Paudel, B.; Hrodey, P.; Muir, A. Alternative Sea lamprey barrier technologies: History as a control tool. Rev. Fish. Sci. Aquac. 2019, 27, 438-457. [CrossRef]

29. Patrick, P.H.; Christie, A.E.; Sager, D.; Hocutt, C.; Stauffer, J., Jr. Responses of fish to a strobe light/ air-bubble barrier. Fish. Res. 1985, 3, 157-172. [CrossRef]

30. Bravo, H.R.; Gulliver, J.S.; Hondzo, M. Development of a commercial code-based two-fluid model for bubble plumes. Environ. Model. Softw. 2007, 22, 536-547. [CrossRef]

31. Turnpenny, A.W.H. Review of Potential for Coarse Fish Entrainment at Potable Water Intakes on the Lower Freshwater Thames (HurleyTeddington); Client Report to Env. Ag. No. FCR 302/99; Fawley ARL Ltd.: Southampton, UK, 1999.

32. Moursund, R.A.; Dauble, D.D.; Langeslay, M.J. Turbine intake diversion screens: Investigating effects on Pacific lamprey. Hydro Rev. 2003, 22, 40-46.

33. Turnpenny, A.W.H.; Taylor, C.J.L. An assessment of the effect of the Sizewell power stations on fish populations. Hydroécologie Appl. 2000, 12, 87-134. [CrossRef]

34. Miranda, L.E.; Hodges, K.B. Role of aquatic vegetation coverage on hypoxia and sunfish abundance in bays of a eutrophic reservoir. Hydrobiologia 2000, 427, 51-57. [CrossRef]

35. Pegg, M.A.; Chick, J.H. Aquatic Nuisance Species: An Evaluation of Barriers for Preventing the Spread of Bighead and Silver Carp to the Great Lakes; Final report for Illinois-Indiana Sea Grant A/SE (ANS)-01-01; Illinois Natural History Survey: Urbana, IL, USA, 2004.

36. Travade, F.; Larinier, M. La migration de devalaison: Problèmes et dispositifs. Bull. Français Pêche Piscic. 1992, 326-327, 165-176. [CrossRef]

37. Solomon, D.J. Diversion and Entrapment of Fish at Water Intakes and Outfalls; R \& D Report No. 1; National Rivers Authority: Bristol, UK, 1992; p. 51.

38. Sand, O.; Enger, P.S.; Karlsen, H.E.; Knudsen, F.R. Detection of infrasound in juvenile salmonids and European silver eels: A mini-review. In Proceedings of the American Fisheries Society Symposium, Bethesda, MD, USA, 8 August-13 August 2001; pp. 183-193.

39. Jones, P.E.; Tummers, J.S.; Galib, S.M.; Woodford, D.J.; Hume, J.B.; Silva, L.G.M.; Braga, R.R.; Leaniz, C.G.; Vitule, J.R.S.; Herder J.E.; et al. The use of barriers to limit the spread of aquatic invasive animal species: A global review. Front. Ecol. Evol. 2021, 9, 611631. [CrossRef]

40. Jesus, J.; Cortes, R.; Teixeira, A. Acoustic and Light Selective Behavioral Guidance Systems for Freshwater Fish. Water 2021, 13, 745. [CrossRef]

41. Welton, J.S.; Beaumont, W.R.C.; Clarke, R.T. The efficacy of air, sound and acoustic bubble screens in deflecting Atlantic salmon, Salmo salar L., smolts in the River Frome, UK. Fish. Manag. Ecol. 2002, 9, 11-18. [CrossRef]

42. Katopodis, C.; Koon, E.M.; Hanson, L. Sea Lamprey Barriers: New Concepts and Research Needs; Great Lakes Fishery Commission: Ann Arbor, MI, USA, 1994.

43. Sorensen, P.W.; Stacey, N.E. Brief review of fish pheromones and discussion of their possible uses in the control of non-indigenous teleost fishes. N. Z. J. Mar. Fresh 2004, 38, 399-417. [CrossRef]

44. Gibbs, M.A.; Glenn Northcutt, R. Development of the lateral line system in the shovelnose sturgeon. Brain Behav. Evol. 2004, 64, 70-84. [CrossRef]

45. Bettoli, P.W.; Maceina, M.J. Sampling with Toxicants in Fisheries Techniques, 2nd ed.; Murphy, B.R., Willis, D.W., Eds.; American Fisheries Society: Bethesda, MD, USA, 1996; pp. 303-333.

46. Haymes, G.T.; Patrick, P.H. Exclusion of adult alewife, Alosa pseudoharengus using low-frequency sound for application at water intakes. Can. J. Fish. Aquat. Sci. 1986, 43, 855-862. [CrossRef]

47. Oprina, G.; Pincovschi, I.; Baran, G. Hidro-Gazo-Dinamica Sistemelor de Aerare Echipate cu Generatoare de Bule; Politehnica Press: Bucureşti, Romania, 2009; pp. 1-176.

48. Brevik, I.; Kristiansen, $\varnothing$. The flow in and around air-bubble plumes. Int. J. Multiph. Flow 2002, 28, 617-634. [CrossRef] 
49. University of Minnesota, Department of Civil Eng. Report regarding Controlling the Movement of Invasive Fish Species Research Contract. 2012. Available online: https:// personal.ce.umn.edu/ \{\}voller/ (accessed on 17 November 2021).

50. Mogdans, J. Sensory ecology of the fush lateral-line system: Morphological and physiological adaptations for the perception of hydrodynamic stimuli. J. Fish Biol. 2019, 95, 53-72. [CrossRef] [PubMed]

51. Popper, A.N.; Schilt, C.R. Hearing and Acoustic Behavior: Basic and Applied Considerations. In Fish Bioacoustics; Webb, F.J., Fay, R.R., Popper, A.N., Eds.; Springer: New York, NY, USA, 2008; pp. 17-48. [CrossRef]

52. Braun, C.B.; Sand, O. Functional Overlap and Nonoverlap between Lateral Line and Auditory Systems. In The Lateral Line System; Coombs, S., Bleckmann, H., Fay, R., Popper, A., Eds.; Springer Handbook of Auditory Research; Springer: New York, NY, USA, 2013; Volume 48, pp. 281-312. [CrossRef]

53. Frizell, W.K.; Arndt, R.E.A. Noise Generation by Air Bubbles in Water: An Experimental Study of Creation and Splitting; Project Report no. 269; Retrieved from the University of Minnesota Digital Conservancy; St. Anthony Falls Hydraulic Laboratory: Minneapolis, MN, USA, 1987; Available online: https:/ /hdl.handle.net/11299/114029 (accessed on 8 December 2021). 